\title{
Bizi-hautuak ertzetatik. Esperientzia agroekologikoen dimentsio subjektiboa trantsizio ekosozialari begira
}

\author{
Vital-choice from margins. The subjective dimension \\ of agro-ecological experiences, lessons for ecosocial transition \\ Jokin Bergara Eguren*
}

\begin{abstract}
Laburpena: Garapen iraunkorraren gaiak oihartzun mediatiko eta politiko geroz eta zabalagoa hartu duen garaiotan, trantsizio ekosozial demokratiko baterako premia aldarrikatzen da sektore akademiko, sozial eta politiko jakinetatik. Aurrekaririk gabeko erronka zibilizatorioaren aurrean, berregituraketa materiala bezain garrantzitsu da trantsizio psikokulturalean arreta jartzea. Artikulu honetan elikadura burujabetzaren bidea hautatu duten gazteen azterketa egiten da, hiriko bizimodutik irten eta automugapenaren eta burujabetzaren ideiari jarraiki eratu dituzten esperientzietan arakatuz. Trantsizio ekosozialaren adar subjektiborako ikasgai baliagarriak ateratzea dugu helburu, bizi-esperientzia automugatuek indibiduoaren mailan dituen inpaktuak eta tentsio-puntu ezberdinak ezagutzeko batetik, eta euren jardunari eransten dioten zentzu sozialetan arakatzeko, bestetik. Interes berezia pizten du ekonomia eta subjektibotasun eredu hegemonikoaren aurrean artikulatzen ari diren bizi-praktika kontra-hegemonikoak ikertzeak, erronka sozio-ekologikorako argi puntu batzuekin topo egin dezakegula sinetsita.
\end{abstract}

Hitz gakoak: Trantsizio Ekosoziala, Subjektibotasuna, Agroekologia, Elikadura Burujabetza, Ekonomia Ekologikoa.

\begin{abstract}
While sustainable development receives increasing media and political repercussion, the need for an eco-social and democratic transition is declared by certain academic, social and political fields. Considering that we are dealing a civilizational challenge without precedents, to focus in the psycho-cultural transition is so important as it is the material reorganization. This article studies young people who have chosen to achieve food sovereignty, inquiring into their experiences leaving the city-life and living in a self-containment and autonomous way. The main objective is to obtain useful learnings for the subjective field of the eco-social transition: on the one hand, to distinguish the impacts and tension points that an individual develops within a self-containment lifeexperience, and on the other, to examine which are the social senses attached to his practice. To investigate counter-hegemonical life practices, which are articulated in front of a normative economic and subjective model, becomes especially interesting, if we assume that they could clear up some keys about the environmental challenge we face.
\end{abstract}

Keywords: Ecosocial Transition, Subjectivity, Agroecology, Food Sovereignity, Ecological Economics.

Econlit: 057-Z10-050

* Harremanetan jartzeko/Corresponding author: Jokin Bergara Eguren. Ikerlaria. Mondragon Unibersitatea (MU) - jbergara@mondragon.edu - https://orcid.org/0000-0002-4574-4308

Nola aipatu/How to cite: Bergara Eguren, Jokin (2021). "Bizi-hautuak ertzetatik. Esperientzia agroekologikoen dimentsio subjektiboa trantsizio ekosozialari begira», GIZAEKOA - Revista Vasca de Economía Social, 18, 75-107. (https://doi.org/10.1387/gizaekoa.22512).

Jasoa: 2021/02/02; onartua: 2021/03/08.

ISSN 1698-7446 - elSSN 2444-3107 / (C) 2021 UPV/EHU

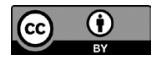

Obra hau Creative Commons Atribución 4.0 Internacional-en

lizentziapean dago 


\section{Sarrera}

Azken hiru hamarkadotan gertatu, garatu eta mamitu diren aldaketa ekonomiko, politiko zein kulturalek (globalizazioa, merkatu ekonomiaren hedatzea, lan-harremanen desarautzea, fordismoaren gainbehera...) egitura eta jarduteko modu kapitalistaren berregituraketa ekarri dute. Desarautze orokortu horrek, auzitan jarri ditu ongizate-estatuaren zimenduak eta biosferaren gainean gizakiak duen eragina azkartu du (Riechmann, 2011). Globalizazio desarautuak eremu sozial eta ekologikoan dakartzan ondorioek geure gizarteak aurrez sekula ikusi gabeko erronkaren aurrean jarri ditu, berrarautze etiko, moral eta kultural baten premian.

Aski ezaguna da Fredric Jamesonek emandako sententzia irmoa: errazagoa da munduaren akabera irudikatzea, kapitalismoarena baino. Mark Fisherrek berak esaldiari lekukoa hartuz dio, zabalduegi dagoela ez soilik kapitalismoa ekonomia antolatzeko modu bideragarri bakarra deneko ideia; are, kapitalismoak alternatibarik izan dezakeelako ustea bera ezinezkotzat jotzen da (Fisher, 2016:22). Ordea, nabarmenak dira krisi sistemikoaren baitan ageri zaizkigun gabeziak: zor krisia, finantza krisia, krisi ekologikoa, osasun krisia, subjektu garaikidearen krisia... aurpegiera ezberdinak eta eragin ezberdinduak ditu gizarte klase eta herrialde bakoitzean. Hala ere, modu bateratuan eragiten du modernitatearen zimendu izan diren zutabeetan eta berauek auzitan jarri. Alternatiba sistemikoa planteatze hutsak ezinezko ariketa dirudi neoliberalismoak indartu duen logika kulturalaren aroan. Emantzipazio proposamenek ez dute gizartean lehen modernitatean bezainbesteko lilurarik sortzen (Wright, 1997).

Dena den, 2015. urteko Parisko hitzarmenean jasotako helburuak betetzeko, komunitate zientifikoaren adierazpenak garbiak dira. Ez dirudi ez garapen jasangarriaren ideiak ez eta energia berriztagarrien inbertsio masiboak helburu horietara hurbiltzen gaituenik, atmosferan pilatzen ari den $\mathrm{CO}_{2}$ maila ikusi besterik ez dago. ${ }^{1}$ Hortaz, gizarte zientzietatik eta komunitate zientifikoaren adar ugaritatik datozen ahotsek naturarekin eta kapitalarekin dugun harremanean eraldaketa sakon baten premia aldarrikatzen

1 Azken mendeko haustura sozio-ekologikoa aztertzea interesgarri zaigu puntu honetan, batez ere bigarren mundu gerratearen osteko aroan. 1950-2000 urteen tartean, gizateriaren lehen iturriko energia kontsumoa bost aldiz biderkatu zen; kontsumoaren gorakada horrek Barne Produktu Gordina zazpi aldiz haztea ahalbidetu zuen eta $\mathrm{CO}_{2}$ emisioak 1950ean halako bost izan ziren 2000. urtean. 1980 urtean, aztarna ekologiko orokorrak planetaren biogaitasuna gainditu zuen eta orduz geroztik atmosferan metatutako $\mathrm{CO}_{2}$ kopurua hazi besterik ez da egin (Fernández Durán eta Gonzalez Reyes, 2014). Zehazki gaur eguneko aztarna ekologikoak planetako biogaitasunaren \%50 gainditzen du. Hau da, 1,5 urte beharko lirateke mundu mailan urte batean kontsumitu duguna planetak berregin dezan (Durán eta Reyes, 2014: 539). 
dute, etengabe haztearen inperatiboak muga biofisikoekin talka jada egin duela jakinik.

Eredu produktiboan eta kontsumo ohituretan trantsizioa beharrezkoa dela inor gutxik ukatzen du komunitate zientifikoan. Baina zein norabidetan gertatuko da trantsizio hori? Krisi ekologiko-sozialak sor ditzakeen ezegonkortasun politikoko egoerak aterabide autoritarioei bide eman diezaieketela planteatzen dute autore batzuek, ekozidioaren ideia planteatzeraino (Riechmann, 2016). Horren aurrean beste ortzimuga demokratiko eta berdinzale bat planifikatzea ezinbesteko langintza zaigula planteatzen dute ikerketa sozio-ekologikoen ildotik (Herrero et al., 2016; Azkarraga, 2014).

Testuinguru arriskutsu honetan, justizia sozialeko terminoetan garatuko den trantsizio antolatu bat irudikatzea funtsezko zeregin bilakatzen da, bestelako gizarte eta ekonomia eredu batera jauzi egin ahal izateko (Löwy, 2011; Schweickart, 2006; Riechmann, 2012): bere inguru biofisikoarekin, termodinamikaren legeekin eta ekosistemen bioaniztasunarekin nolabaiteko oreka lortuko duena. Bestela esanda, ekologiki eta sozialki justuagoak, berdinzaleagoak eta demokratikoagoak izan daitezkeen gizarte ereduetara bide egiteko aukera zabaltzen da. Bide hori egin ezean, erregai fosilen agortzeak, berotze globalak, eta sakontzen ari diren arrakala sozialek ezegonkortasun handiko egoera soziopolitikoetara bultza gaitzakete. Krisi sozio-ekologikoak beraz, mende hau ezaugarrituko duen erronka erraldoia jartzen dio parean gizarte garaikideari, sakoneko egiturazko eraldaketak eskatzen dituena ezinbestez, edo historian egon diren zibilizazio kolapsoen zerrendara beste bat gehitu (Diamond, 2006). Sozio-ekologiaren ikuspuntutik, erresilentzia prozesuak azkartzeko kontsumo kultura errotuaren norabide aldaketa beharrezkoa da, justizia klimatikoko terminoetan trantsiziorik gertatuko bada.

Bada, norabide horretan bultzaka ari diren esperientziak ezagutze aldera, artikulu honetan trantsizio ekosozialean sakondu duten praktika agroekologikoak aztertu ditugu. Deskribatu berri dugun testuinguru sozio-historikoan interes soziologiko berezia pizten du praktika horien azterketak: batetik, balizko trantsizio baten aurrean kolektiboki baliagarri izan daitezkeen ikasgai batzuk lortzeko balio dezake; bestetik, pertsona horien arrazoietan, eguneroko bizitzaren soziologian eta dituzten gatazka eta tentsio puntuetan sakontzean gure gizartearen paradigma kultural hegemonikoekin talka egiten duten ezaugarriekin topo egin dezakegu. Ondorioz, gure gizarteen azpikorronteetan martxan dauden prozesuen berri emateko moduan egongo gara; helburua esperientzia horietan konfigurtazen den errealitate sozialaren berri izatea da, trantsizio ekosozialarekin lotura estuan.

Zehatzago esateko, elikadura burujabetzarekin loturik agertzen diren esperientziak ikertu ditugu; zeukaten bizi-estiloa eraldatu eta nekazaritza 
proiektuetan sartu diren gazteak, euren buruak hornitu eta proiektu sozioekonomiko ezberdinei bide eman dietenak, ekonomia ekologikoaren ildotik. Beraz, esperientzia emantzipatzaileak, ertzetatik egin izan diren bizi-hautu alternatiboak izango dira lan honetan zehar aztertuko direnak. Molde psikosoziologiko berri batekin eta baserriaren inguruko identitate berrituarekin dabiltzanak euren bizimodua gorpuzten.

Zeregin hori burutzeko hiru atal nagusitan banatu dugu artikulua: i) Helduleku teorikoak, hiru azpiataletan banatua. Lehendabizi nazioarte mailan artikulatu diren trantsizio mugimendu batzuen berri emango dugu, gizarte mugimenduen soziologiaren ikuspegitik eta Ekonomia Sozial eta Solidarioarekin lotura eginez. Ondoren, postazkundearen erronkari erreparatuko diogu, arreta puntua bere dimentsio psikokulturalean jarriz. Hirugarrenik, Euskal Herrian zehar garatu den elikadura burujabetzaren auzia eta agroekologiatik eratzen ari den mugimendura begiratuko dugu. ii) Atal enpirikoa. Artikuluaren zati honetan, ohar metodologikoarekin hasi eta jasotako material diskurtsiboaren analisia egin da, atera diren gai adierazgarrienekin egituratua. iii) Artikulua ixteko, zenbait ondorio nagusi adierazi nahi izan ditugu, gazteen fenomeno agrokulturala hobeto ulertzen saiatzeko batetik, eta etorkizunera begira sakon daitezkeen iker-ildoak finkatzeko, bestetik.

\section{Helduleku teorikoak}

\subsection{Agroekologia mugimendu zabalgoen baitan, ertzetako bizi-hautuen soziologia}

$\mathrm{Ez}$ da berria merkatu ekonomiari edo estatuen botere neurrigabeari kritika zorrotza egin eta bizi-hautu propioak abiarazi dituztenen zerrenda. Ideologia politiko ezberdinen babespean (pentsamendu ildo libertariotik hasi eta katolizismoraino) ugariak dira historian zehar topa ditzakegun adierazpen kontra-hegemoniko edo antisistemikoak. Ordea, trantsizio ekosozialak eskatzen duen konpromiso maila bere egin eta horren ondorioz antolatu diren komunitaeteen edo esperientzien hedatzea fenomeno berria da Euskal Herrian, prozesu sozial eta ezinegon zabalago baten adierazle.

Lehenik eta behin, Ekonomia Sozial eta Solidarioaren (ESS) proposamen teorikoak, marko teoriko aproposa eskaintzen digu agroekologiaren postulatu batzuk ulertzeko. Jean-Louis Laville (2010) soziologo ekonomikoak dio, ESS-a birbanaketaren eta parekotasunaren printzipio demokratikoetan errotzen dela, eta praktika ekonomikoak kontrol sozial zabalagoen baitan instituitzea duela helburu. Garaiak eskatzen dituen erronka sozial eta ekologikoen aurrean, ESS-an oinarritzen diren ekimenek antolakunde 
eredu berriak eraiki nahi lituzkete, gizartearen beharren eta praktika ekonomikoaren arteko zubi zuzenak sortuz. Ez da soilik testuinguru zehatzean dauden konfigurazio soziopolitiko eta sozioekonomikoetan eraldaketa jakinak bilatzen dituztela, begirada zabalagoa egiten dute bere, soziala, ekonomikoa eta ekologikoa mahai beraren hiru hanka bereiziezin direla iritzita. Horrela, ESS-ak herritarren segurtasun materiala eta praktika ekonomikoaren demokratizazioa bilatzen du, krisi testuingu batean arrakalatu diren gizarte ezberdintasunen eta ziurgabetasun materialaren aurrean erantzun demokratizatzailea emateko (Laville eta Garcia, 2009). Hain justu, hauek dira sozioekonomikoki antolatzeko era berritu honen oinarrizko postulatuetako batzuk: i) enpresako barne-demokrazia ii)soldata berdintasuna iii) erantzukidetasuna iv) ekologikoki jasangarria den produkzioa v) denboraren banaketa justua eta abar.

Riechmann eta Carpinteroren arabera (2013) Ekonomia Sozial eta Solidarioan mekanismoak garatzen dira erregimen soziometabolikoa eraldatzeko, justua izan dadin oraindik jaiotzeke dauden belaunaldiekin eta haiek euren beharrak asetzeko izango dituzten ondasun materialekin. Era berean, planetaren muga biofisikoekiko kontzientzia-hartze prozesu sendoa bizi da eremu eraldatzaile horretan, eta horrek auzi ekologikoarekin arduraz jokatzeko bideak zabaltzen dituela diote Riechmann eta Carpinterok, ekonomia sozial klasikoan gertatzen ez den modu batean. Eremu eraldatzaile hori ekoizpenetik hasi (nekazaritza agorekologikoko kooperatibak bertan leudeke, energia produkzio edo finantza etikoekin batera) eta kontsumoraino iristen da (kontsumo taldeak, denbora bankuak...). Autore horiek, leku horretan jartzen dute ekonomia sozial eraldatzaileak dakarren indarguneetako bat: gizarte jasangarrietarako trantsizioa nola egin beharko litzatekeen eztabaida mahaigaineratzen du. Ekoizteko eta kontsumitzeko modu berritua eskaintzeaz gain, trantsizio sozio-ekologikoaren prozesuan ardatz nagusietakoa izango direla diote, eta hortik prozesu horiek xeheki ikertu eta zaintzearen garrantzia (Riechmann eta Carpintero, 2013: 90-91).

Nabaria da beraz ESS-ak herri mugimenduekin duen lotura, Marie Bouchard (2011) soziologo kanadiarrak dio Ekonomia Solidarioak paradigma berria eskaintzen duela erakunde, enpresa eta herri mugimenduen arteko harremanak lantzeko, herri mugimenduak eta komunitate lokalak izanik praktika ekonomiko eraldatzaile horiei forma emango dietenak eta euren errealitate sozialean gorpuztuko dutenak.

Bada, praktika ekonomiko berritzaile horiek burutuko dituen subjektuaren auzira jo behar dugu segidan, eta hor herri mugimenduen soziologiarekin egiten dugu topo ezinbestez. Oro har mugimendu konprometituak ez dira hutsetik sortzen, magma kultural eta ibilbide historiko baten oinordekotzatik baizik. Bestela esanda, testuinguru historiko zehatzean jaiotzen dira "gizarte eragile, talde, antolakunde eta mugimenduak... arau- 
sistemen eramaile eta sortzaile dira aldi berean, gizarte egiturak ezartzen duen arau sistema dute beren baitan, baina era beran, arau-sistema horiek eraldatzen dituzte euren ekintzen eta jardunaren bidez» (Burns et al., 1985: iv).

Sztompka-k dio gizarte mugimendua beti dagoela baldintza historiko jakinetan emana, eta bere eginkizuna izan ohi dela oinordekotzan datozkien ikuspuntuak, ohiturak, jardunbideak eta motibazioak sailkatu, aukeratu eta modu berri batez ordenatzea (Sztompka, 1987). Berritasunaren itxura izanagatik, sekula ez da modu absolutuan izango, aurrez ezagunak ziren kode batzuei erantzungo die, ez da izango ezerezetik sorturiko zerbait.

Esan bezala, paradoxikoa bada ere, bizitzaren alderdiak ostera ere kontrolatzeko nahia ageri da, berau arautu eta kudeatzekoa, bios-aren gaineko kontrola izatea, hots, bioboterea (Hardt eta Negri, 2002). Egun planteatzen diren borrokak ez dira soilik eremu batera mugatzen, ekonomikora adibidez; aitzitik, borroka ekonomiko, politiko eta kulturalak dira aldi berean, bizitzaren jabetza berreskuratzeko borrokak, burujabetza bere zentzu zabalean eskatzen dutenak, hortaz, aldarri biopolitikoak.

Funtsean, termino Habermasianoetan esateko, bizitzaren mundua arrazionaltasun instrumentalak (sistemak) ez kolonizatzeko hautua egitea da planteatzen den auzia. Arrazionaltasun tekniko-utilitarista balio-egitura jakinetan murgilduko duten komunitateak eskatzen ditu trantsizio sozialki eta ekologikoki justu batek. Bere buruaren jarduna automugatzen jakingo duen komunitatea, oreka dinamikoan eta ekosistema biziekin elkarbizitzan funtsatua.

Subjektu kolektibo berri horien agerpena Marcuseren esaldi esanguratsu batean laburbildu liteke:

Desde esta realidad es desde donde está surgiendo, recuperando una hermosa expresión de Marcuse (1979), esa "rebelión del instinto de vida contra el instinto de muerte socialmente organizado" que caracteriza a los movimientos sociales de hoy. Recuperar las condiciones para una vida realmente humana, tal es el desafio. (Zubero, 2012: 24)

Askotarikoak dira munduan zehar arrazionaltasun ekosoziala garatu eta bizi-praktika eraldatu duten esperientziak. Besteak beste, adierazten dituzten printzipioen artean ondoko hauek zerrendatu ditzakegu: garraioa (publikoa) beharrezkoa denean soilik erabiltzea, bertako produktuak kontsumitzea (ekologikoki landatuak), haragi gutxiago kontsumitu, energia berriztagarrien aldeko hautua, gutxiago bidaiatu, giza harremanei lehentasuna eman, bizitzaren erritmoa apaldu, mantsotu... Esperientzia eta ekimen ezberdinduak badira ere, ezaugarri bateratu batzuk identifikatu ditzakegu: i) maila lokalean ardatzen dute euren jarduna ii) komunitatearen 
autonomia maila altua aldarrikatu eta bilatzen dute iii) unibertsalki aplikagarri diren ereduen aurrean, jakintza kokatuak erabiltzen saiatzen dira. AEB-tan bizimodu zehatz hau daramatenak LOHAS mugimenduko kide gisara sailkatu dira, Lifestyles of Health and Sustainabillity.

Adibide praktiko esanguratsu bat ekoudalerri-ena da. Suedian du sorleku, eta proiektuak Overtomea izeneko udalerri suediarrean du jatorri. 5000 biztanleko herri honek, 1983an jarri zuen ekimena martxan, erregai fosilekiko, produktu kimiko-sintetikoekiko menpekotasuna ezabatu, giza harremanak hobetu eta naturaren kolonizazioa gelditu asmoz. Esperientzia hori abiapuntutzat harturik, maila nazionalean hedapena lortu du, suediako udalerrien \%25eraino iritsi da (tartean 300 biztanleko herri txikiak edo Estokolmo gisako hiriak).

Bestalde, Trantsizio komunitateak ekartzea ere interesgarria zaigu. Ekimen hau, trantsizio mugimenduaren barruan koka dezakegu ${ }^{2}$, sei urteko epean 30 estatutara zabaltzea lortu duen mugimendua, hain justu. Finean, esaten gatozenaren haria jarraitzen dute hauek ere, ekonomiaren tokian tokiko burujabetza berreskuratzeko saiakera eginez, gizarte bizitza parte-hartzaileagoa antolatzearekin batera. Oinarrizko adostasuna soilik eskatzen zaie partaideei, aldaketa klimatikoa eta egun ezagutzen dugun ekoizpenkontsumo ereduaren amaiera badatozela onartzea.

Ekoudalerrien antzera, Transition Town dei ditzakegunek ere izan zuten beren aurrekaria. Kinsale, hego Irlandako herria, izan zen ekimena aurrera eramateko hautatu zutena Kinsale 2021 izenburua izan zuen proiektuarekin. Bertan, energia menpekotasuna murrizteko plangintza parte-hartzailea jarri zuten abian $\mathrm{EDAP}^{3}$, erregai fosilik gabeko mundua irudikatuz jardungo zuena. Kinsalerena, ordea, teorizazio hutsa izan zen eta, praktikan, 2006an jarri zuten Ingalaterra hego-mendebaldeko Totnes herrian. Gerora, ekimena saretu eta mamitu da Transition Network (Trantsizio ekimenen sarea) moduko tresnak sortu eta erabiliz.

Guzti honek oinarrian behar lukeen eraikuntza ederto azaldua dator aipu honetan:

A futuro, son muchos los autores que hablan de la necesidad de recuperar el espacio de lo comunitario, es decir, de proteger los ámbitos de la vida

2 Trantsizio mugimenduaren sareak erresilientzia gaitasuna areagotzea du helburu, nazioartean eratzen ari diren esperientzia komunitario ezberdinak saretuz eta antolakuntza marko bat eskainiz ildo beretik tira egiten duten proiektu ezberdinei. Beren buruaren aurkezpena eta mugimenduaren arrazoiak sakonago arakatzeko ikus web orrialdea, esteka honetan eskuragarri: https://www.reddetransicion.org

3 Siglek ingelesez Energy Descent Actioning Plan esan gura dute. Kinsale 21i buruzko xehetasunak esteka honetan eskuragarri: https://www.transitiontowntotnes.org/ 
social en el que se produce la comunicación simbólica y se da la producción, transmisión y socialización de los valores colectivos. Todo ello apunta hacia la necesidad de construir un nuevo equilibrio entre el mercado, el estado y la comunidad (la sociedad civil), a partir del reforzamiento de esta última. (Azkarraga et al., 2011: 85).

Beste kasu adierazgarri bat genuke sinpletasunaren bidea hartzeko hautua egin dutenena. The Simpler Way deitu izan zaio, oinarrian, aipatzen gatozenaren ildoa jarraitzen duena. Diotenez, soiltasunez bizitzeak, alegia, kontsumo desio amaiezinaren neurrietatik kanpo, bizitza hobeak eta aberasgarriagoak ekar ditzake (Trainer, 2015). Funtsean, egoteko eta egiteko bestelako modua dakar sinpletasunaren bidearen ideiak; beste psikopolitika bat, subjektuak bulkada kontsumitzailetik atera eta post-hazkunderako prestatuko dituena. Labur esanda, eredu horiek guztiek sakonean mutazio antropologiko bat bilatzen dute, gutxiagorekin ondo bizi daitekeeneko ideia mahai gainean jarrita.

\subsection{Postazkundea, automugapena eta trantsizioaren ertz psikokulturala}

Hazkundearen ideia hedatua sostengatzen duen mundu ikuskeran funts kultural zehatza nagusitzen da, giza-sistemak sistema naturaletatik kanpo definitzetik datorrena (Azkaraga et al., 2011). Modernitate industrialaren etorrerak zutabe kultural berriak ezarri zituen, eta giza jardun ekonomikoa sistema biosferikoaren baitan murgildu beharra garaiko imaginario kulturaletik aldendu zen. Ordea, nabarmenak dira konfigurazio psikokultural horrek indarrean dagoen garapen ereduarekin dituen sinergiak, eta horrek dakartzan ondorio kaltegarriak ertz sozial eta ekologikoan. Testuinguru horretan, hazkunde eredu neoliberalarekin bukatu eta hazkunde-osteko garai soziopolitiko batera jauzi egiteko premia aldarrikatzen da pentsamendu sozio-ekologikotik, hazkuntza berdearen gauzapena ezinezkoa dela iritzita (Tanuro, 2011).

Ildo honetan kokatzen den autore garrantzitsu bat aipatzekotan Jorge Riechmann pentsalaria dugu. El siglo de la Gran Prueba (2013) liburua abiapuntutzat harturik, gure gizarteen autosuntsipenerako joera aztertzen du. Esaterako, Kevin Anderson sona handiko klimatologoaren lana aipatzen du, Tyndall Centre of Climate Research-eko kidea bera. Dioenez, erakunde politiko nagusiek lur planetako hozberoa bi gradu soilik igotzeko helburua bete nahi bada, 2013. urtetik hasita gure berotegi-efektuko gasen isurketak urtean $\% 8$ eta $\% 10$ inguru jaitsi beharko lirateke. Azken hamarkadotan izan dugun bilakaera aztertuz, oso zail izango zaigu kopuru horietara iristea, izan ere, 1960. hamarkadan atmosferara isur- 
tzen zen $\mathrm{CO}_{2}$ kopurua, 0,7 ppm (parts per million) zen urteko. Azken urte honetan 2,8-2,9 ppm-ko isurketak izan dira kopuru globalean. Atmosferako $\mathrm{CO}_{2}$ kontzentrazio tasaren serie historikoa begiratzen badugu, hazkuntza linealarekin egingo dugu topo ${ }^{4}$ : 1958an 315,24 ppm-ko tasa, 1978 an 335,40 ppm, 1998an 366,7 ppm eta 2018an 408,56ko tasa neurtu zen 5 .

Zentzu berean, gaurko hazkundea posible egiten duen eredu energetikoak sortzen dituen ondorio sozioekologikoek ilustra dezakete postazkundearen planteamenduaren garrantzia (Atutxa eta Zubero, 2019): i) zor ekologikoa, industrialki oso garatuak dauden herrialdeek energia dosi erraldoiak behar dituzte euren ekonomiak mugiarazteko eta horrek etorkizuneko belaunaldiak zein ekosistema biziak hipotekatzen ditu ii) energia jabetza monopolikoetan metatzeak energiaren produkzio eta erabileraren gaineko erabaki demokratikoa ezinezko bilakatzen du iii) eremu energetikoa desberdintasun sozialen iturri da, energía kontsumo ahalmen handia dutenen (herrialde aberatsak-klase aberatsak) eta energiara sarbide mugatua dutenen (hegoaldea eta klase subalternoak) arteko arrakala areagotzen $\mathrm{du}$. Are gehiago, herrialde aberats industrial aurreratuek euren ekonomien nolabaiteko desmaterializazioa garatzen ari direla badirudi ere, ekonomia ekologikoaren ikuspegitik ezer gutxi aldatzen da, izan ere, herrialde periferikoetara esportatzen dute zor ekologikoa deslokalizazio industiraleko prozesuen bidez (Naredo, 2006).

Alabaina gizarte modernoetan errotuta dauden bizi-estilo eta praktika sozioekonimokoentzako funtsezkoa da eredu energetiko horren mantenua. Bai klase sozial altuetan zein herri klaseetan dagoen kontsumo kopuruak zor ekologikoko tasa altua sortzen du. Riechmanek «hitzarmen sozial neoliberala» hartuko du langile klaseak eta klase prekarioak energia kontsumo altuetara iristeko duten joeraren arrazoitzat (Riechmann, 2015). Bere arabera, subjektu modernoari lan prekarioak eta lan merkatu ezegonkorra eskaintzen zaion era berean, aisialdi merkea jartzen dio eskura, merke bidaiatzeko, merke jateko edo merke horditzeko aukera eskainiz. Emantzipazioaren ideia, guztiontzako oparotasuna izango duen agertokian baino, gutxiagorekin bizitzeko irudian zentratu beharra azpimarratzen du, klase bereizketa bainoago, krisi ekologikoa eragiten duena geure gizarteen lilura produktibista baita. Bada, post-hazkundeko agertoki batean, eredu energe-

${ }^{4}$ Iturria: Observatorio de la Sostenibilidad 2019-ko txostena. 20 urteko tarteetan emango ditugu datuak, denbora tarte berbera errespetatuz kontzentrazio tasaren eboluzioa modu argiagoan islatzeko.

5 Datu adierazgarria da 2020koa. Covid19aren pandemiak eragindako geldialdi ekonomikoak mugikortasuna izugarri mugatu badu ere, atmosferan metatutako $\mathrm{CO}_{2}$ kopuruak ez du atzera egin, eta 413,89ko kopurura iritsi da. Meteroelogiaren Munduko Erakundea (2021). 
tiko horren berregituratze sakona agindu ukaezina da, eta garapen ereduaren zein bizimodu onaren berrikuspen pausatua eskatzen du.

Labur esateko, planteatzen zaigun bidegurutzea ez da soilik aberastasuna zati berdintsuagoetan banatzea, aberastasuna bera termino materialetatik haratago birdefinitzea baizik. Hau da, trantsizio ekosozial arrakastatsua, izatekotan, aldi berean izango da materiala eta kulturara. Postazkunderako trantsizioak bietatik eskatuko du: i) metabolismo sozialaren eraldaketa sistemikotik, BPG moduko adierazleak fetitxizatzeari lagako diona ii) kontsumo gizartetik haratago iritsiko den kulturatik, bizimodu asegarri, duin, aberats edo onaren definizioa muga biofisikoen barruan integratzen asmatuko duena.

Badago ordea sakoneko kontsumo eta produkzio erak aldatu barik aterabiderik proposatzen duenik. Bertatik proposatzen den bidea geoingeniaritzarena da, zeinak ez dirudien oso egingarria. Antonio Turiel-ek (2012) (CSIC-eko zientzialari eta OIl Crash Observatory-ko zuzendariak) egun espainiar Estatuan kontsumitzen diren 6 exajulio-ak iturri berriztagarrietatik soilik kontsumitzeak zer kostu lekarkeen kalkulatu zuen. Ondorioa, 4,12 bilioi dolar beharko lirateke azpiegituren aldaketak egiteko, espainiar Estatuko BPG-aren hirukoitza eta, 32 urteko denbora tartea, hau guztia ekonomikoki ia etekinik emango ez lukeela jakinda. Turiel berak dio, ebidentea dela merkatu ekonomian ardaztutako sistema batean, ez dela maila horretako inbertsiorik egingo, errentagarritasunik ia emango ez duela jakinda (Turiel, 2012: 23).

Zentzu berean, García Olivares zientzialariaren lana ere aipatu dezakegu (CSIS-eko zientzialaria hau ere). Mundu mailako energía kontsumoa $\% 100$ jasangarria bilakatzeko aukera kalkulatu du: zientzialariaren arabera, posible litzateke 2005. urtean mundu mailan eman zen kontsumo energetikoko tasa mantentzea, industria petrokimikoaren kasuan izan ezik (García Olivares et al., 2012). Sektore horrek 80. hamarkadako energia produkzio tasetara itzuli behar luke. Gainerakoan, energia produkzio sistema eguzkienergian eta eolikoan ardaztu beharko litzateke, tokian toki bestelako sistema berriztagarri batzuekin konbinatuz (hidroelektrikoa, itsas-energia...). Noski, elektrikoak ez diren sistema produktiboak elektrifikazio prozesu batean murgildu beharko lirateke, eta ikerlan honen interes puntuari dagokionez, beharrezkoa litzateke nekazaritza eremuan berregituraketa agroekologiko masiboa. Hori guztia, 40 urte inguru iraungo lukeen gerra-ekonomia baten bidez gauzatzea ikusten du posible, gaurko gizarteak dituen espezializazio, sofistikazio eta konplexutasun mailak nolabait mantendu gura badira.

Bada, teknologiak eskaini dezakeen konponbidea mugatua eta gatazka puntuz betea egonik, automugapenaren ideiak garrantzia berezia hartzen du bidegurutze historiko honetan. Ideia horretan barnebiltzen da trantsizio ekosozial demokratiko eta antolatu baterako gakoa, eta ez horrenbeste tek- 
nologia berdearen garapenean edo ekonomia digitalaren ${ }^{6}$ etorreran. Hala dio Joaquim Semperek:

Gizarte produktibista-kontsumistak geroz eta espektatiba material altuagoak eraikitzen ditu. Modu horretan, hazkunderako joera elikatzen da baina ondorio psikologiko eta moral suntsitzaileekin. Satisfakzio eza erreproduzitzen da etengabe, eta era berean gehiagorako nahia elikatu. Geure espektatiben eraikuntza kontrolatzen ikasi behar dugu, psikikoki arrazoizkoa eta ekologikoki posiblea den neurrira egokituz. Hitz gakoa automugapena da. (Sempere, 2016)

Borondatez gutxiagorekin bizitzeko erabakia hartzeak ordea, korapilo antropologiko problematikoa planteatzen digu, izan ere, gizarte zientzietatik bizimodu onaren gaineko definizio ariketa bat egin beharko genuke, oparotasun materialak azken hamarkadak ezaugarritu dituen gizarteetan. Gutxiagorekin bizitzeko esperientzia aberatsen eraikuntzan dago arazo estrukturaletako bat, termino Gramsciarretan hegemoniko izatera igarotzean, alegia.

Protesta edo kontrabotere molde klasikoak antolatzetik haratago, beren behar material-produktiboak mugatu eta alternatibak ${ }^{8}$ eraikiko dituzten komunitateak ezinbesteko eragile bilakatzen dira postazkunderako trantsizioa modu ordenatu eta ahalik demokratikoenean egite bidean. Aipatu ditugun trantsizio esprerientziez gain, elikadura burujabetzarekin lotuak dauden ekimenak (La Via Campesina, Etxalde, Baserria XXI) aipatzea dagokigu. Guztiek ere ekonomiaren birtokiratzearekin, komunitateen berrindartzearekin eta harreman sozioekonomiko tradizionalagoetara itzultzearekin (baserriaren pisua esaterako funtsezkoa da esperientzia horien guztien artikulazioan) dute zerikusia.

Ez dago oso argi ordea zein izan daitekeen post-hazkundeko agertoki posible hori. Jabetza konpartituaren, komunaren, edo prokomunaren ideiek indar berezia hartzen dute eremu akademiko jakinetan, trantsizio

${ }^{6}$ Internetek, datu-baseen gordelekuek eta gailu teknologiko kopuru erraldoiak mineral jakinen eta energia kopuruen beharra dute ekoitzi eta jardunean iraun ahal izateko. Bada, desazkunde energetiko baten testuinguran nekez izango da posible gizarte digitalen orokortzea (Durán eta Reyes, 2014).

7 Itzulpen propioa. Fuhem Ecosocial, 2016ko abenduaren 5a.

8 Soussa Santos eta Rodriguez (2007) autoreek alternatibo hitza darabilte kapitalismoaren hiru ezaugarri hauek gainditzeko helburuarekin lanean ari diren praktikak izendatzeko: i) desberdintasun sozial eta ekonoimikoen logika estrukturala ii) elkartasunean baino, etekin pribatuan oinarritutako arrazionaltasuna iii) baliabide naturalen erabilera masiboa, lur planetan gizakiak duen bizirauteko probabilitatea murrizten duena. Hiru ezaugarri horiek gainditzeko saiakeran dabiltzan praktika sozioekonomikoez ari gara «alternatibo» hitza erabiltzen dugunean. 
ekosozialerako eredu apropos modura (Atutxa eta Zubero, 2019). Argi dagoena da ekoudalerriek, trantsizio herriek edo sinpletasunaren bideak norabide bat erakusten badute ere, trantsizio ekosozial orokorrak, dimentsioan, konplexutasunean eta antolakuntza mailan askoz sistema sofistikatuagoak eskatzen dituela. Ordea, bizipen mailan dakartzan inplikazio material eta subjektiboei dagokienez ikasgai interesgarriak atera ditzakegu bertatik. Horra hor ikerketa honen ekarpena, jada martxan dauden automugatutako esperientzien ezagutza jasotzea lehen eskutik, norbanakoaren dimentsioan zein talka eta gatazka puntu ekar ditzakeen irudikatzeko batetik, eta zein abantaila edo aberastasun puntu lor daitezkeen zerrendatzeko, bestetik. Baliabide gutxiago kontsumituz bizitzea errealitate materialak inposatuko duen agertokia izanik, sekula baino interes gehiago hartzen du gaur bizi-estilo horietatik gertu egon daitezkeen bizipenetan, diskurtsoetan eta eraikitzen dituzten esanahi sozialetan arakatzeak.

\subsection{Elikadura burujabetza, proposamen agroekologikoaren indarra}

Elikadura burujabetzaren auziak pisu berezia hartzen du globalaren eta lokalaren arteko orekaren bilakuntzan, bertako ekonomia zirkularraren indartzean eta trantsizio ekosozialak eskatzen dituen bestelako eraldaketa estrukturaletan. Zehaztu beharra dugu elikadura burujabetzaz ari garenean La Via Campesinak Nyéléniko adierazpenean (2007) jasotzen duen definizioak ematen dion zentzuan erabiltzen ari garela:

Elikadura burujabetza herriek elikagai nutritibo eta kulturalki egokiak kontsumitzeko duten eskubidea da. Modu jasangarri eta ekologikoan ekoitzitako produktuak, hain justu. Era berean, elikadura sistemaren eta sistema produktiboaren gainean erabakitzeko eskubidea izatea da. (Nyéléni, 2007) ${ }^{9}$

Burujabetzaren ideiak ${ }^{10}$ elikaduraren alorrean hartzen duen formari egiten zaio erreferentzia, erabakitzeko boterea nekazarien, abeltzainen eta

9 Itzulpen propioa Nyéleni 2007ko adierazpenetik. Adierazpenaren bertsio osoa hemen eskuragarri: https://nyeleni.org/spip.php?article291

Itzulitako testua gazteleraz: «La soberanía alimentaria es el derecho de los pueblos a alimentos nutritivos y culturalmente adecuados, accesibles, producidos de forma sostenible y ecológica, y su derecho a decidir su propio sistema alimentario y productivo.»

${ }^{10}$ Interesgarria litzateke burujabetzak bere zentzu ezberdinetan dituen esangurak eta inplikazioak aletzea. Herri batek autogobernatzeko dituen erakunde politikoez (estatua) haratago doan auzia da, egitura ekonomiko, nazioarteko banaketa kate, finantza jario edo energia sortu eta banatzeko azpiegituren kontrolarekin zerikusia duena. Elikadura burujabetza ere, funtsean, 
herritarren gain jarriz. Indarrean dagoen erregimen metabolikoan haustura-puntuak eragiteko baldintzak sortzen ditu, boterea demokratizatzearen bidez. Euskal Herriari begiratzean ordea, prozesu makroekin lotura estuan (globalizazioa, industrializazioa, herrien metropolizazio azkarra...) nekazaritzak eta abeltzaintzak biztanleriaren horniduran izan duen pisua nabarmen jaitsi da. 1999-2009 urteen artean EAEko baserri kopuruak \%33,5 egin zuen behera eta nekazaritzaren pisu ekonomikoa Erkidegoko Barne Produktu Gordinaren \%0,49a soilik izan da, biztanleria aktiboaren \%1a, hain justu (Azkarraga eta Aurélie, 2017).

Baserriak euskal iruditerian eta bere errelato nazionalean protagonismoa mantentzen jarraitzen badu ere, mende hasierako datuek baserriaren gainbehera nabarmena erakusten dute, gizarte urbanoagoetara pasatu garela adieraziz. Ordea, euskal herritarrek kontsumitzen dituzten elikagaien $\% 7$ a soilik da inguruko nekazaritza sektoreak ekoitzitakoa, gehienetan bide ez agroekologikotik.

Ordea, baserriaren oinordekotza eta iruditeriak presentzia kultural nabarmena izanik, ugari dira azken urteetan baserrira itzultzea erabaki duten gazteak. Faktore askorekin lotua dagoen fenomenoa bada ere (bizimodu urbanoarekiko ukoa, lasaitasun nahia, kritika politiko erradikala, jokabide anti-modernoa, norbere nortasunaren eraikuntza alternatiboa...) nekazaritza agroekologikoa ardatz harturik abiatu diren esperientzien ugaltzea identifikatu dezakegu (Begiristain et al., 2019), nahiz eta kopuru absolututan esperientzia marginalak izaten jarraitu.

Edozelan ere, elikadura burujabetzaren eta proposamen agroekologikoaren ideiak indar-hartze prozesua bizi du. Horren erakusgarri da EHNE Bizkaia moduko erakundeek sustatzen dituzten ikastaro agroekologikoetan, 1.000 partaidetik gora izena eman izana (Azkarraga eta Aurélie, 2017). Diskurtso agroekologikoak sektore sozial jakinetan errotzea lortu du, eta hortik ekimen ezberdinen taupatzea. Beraz, neurri xumean bada ere, gazte belaunaldien berbaserriratze prozesu baten aurrean gaude.

Prozesu honen garrantzia azpimarratu gura dugu, elikadura burujabetza trantsizio ekosozialaren funtsezko adarretako bat izango dela ohartarazten baitute zenbait autorek. Horrenbestez, elikadura burujabetza eta nekazaritza agroekologikoa txanpon beraren bi aldeak lirateke, batak iparra marrazten duena eta besteak bertara iristeko ibilgailua.

Besteen artean, honako ezaugarri hauek zerrendatu ditzakegu nekazaritza agroekologikoaren adierazgarri modura (Calle et al., 2011): i) elika-

auzi politikoa da gainontzeko burujabetzak (energia, finantza, garraioa, telekomunikazioak...) eskuratzeko estrategiaren baitan ulertu beharrekoa. Dena den, artikulu honen luzeeratik eta helburuetatik gaindi kokatzen da subirautzaren gaiaren esposaketa sakona, zeintzia politikoetan, historian edo nazioarteko harremantean horren eztabiadatua. 
gaien segurtasuna bermatzen du produzkio ekologiko eta ez kimikoaren bidez ii) agroindustriaren ingurugiro kaltea murrizten du iii) funtzio ekosistemikoak errezten ditu iv) eskala txikian gertatzen da, bertako ekonomia kalitatezko produktuz hornituz v) landa eremuko garapena ahalbidetzen du, globalizazio agroalimentarioa ez den norabide batean vi) ekintza kolektiboa du ardatz, agroekosistemak irizpide ekologikoekin kudeatzeko batetik, eta guztien oinarrizko beharrizanak era ekitatiboan asetzeko, bestetik.

Gidoi prefiguratu, itxi eta bukatua izan barik, proposamen agroekologikoak itxura eta praktika multzo ezberdina hartzen du tokian tokiko baldintzen arabera. Dena den, guri interesgarrien zaiguna gazteen ekintza zentzuz hornitzen duen oinarria ikertzea da, bai adar ekonomikoan, politikoan zein kulturalean.

\section{Atal enpirikoa}

\subsection{Ohar metodologikoa}

Euskal Herrian zehar garatu diren proiektu agroekologiko ezberdinetan parte hartzen duten kideak izan dira hautatuak elkarrizketa hauek egiteko. Landuko den eremua, hortaz, euskal gizarteari dagokio, aurrez azaldu diren esperientzien gisako (The Simpler Way, ekoudalerriak, LOHAS...) mugimenduetan kide aktibo direnengan ardaztuko dena. Automugapenean ardaztutako proiektuak izaki, hirietatik baserrira edo landa-eremura joandako praktika alternatiboak dira aztertu direnak. Era berean, esan beharra dago, mugimendu hauen ezaugarri berberak dituzten esperientziak aurkitzea ez dela helburua, gordetzen dituzten mundu ikuskera eta esanahi sozial partekatuak aletzea baizik. Zehazki honako Iker-galderak planteatu ditugu. Nola ezaugarritu dezakegu mugimendu hori? Zein perfil soziologiko daukate? Zein ildotako gizarte aldaketa bilatzen dute? Zer dute motibazio nagusi? Zein zentzu eransten diote euren jardunari? Galdera horiei erantzuten saiatuko gara ondorengo orriotan.

Elkarrizketatuak aukeratzeko orduan, ondoko irizpide hauek izan ditugu kontuan: i) Kalean jaio eta hezi izana eta beren baserri bizitzarako jauzia gaztaroan hartu izana. ii) Adina, 35 urtetik beherako adina izatea. iii) Agorekologiaren proposamena bere egin eta ekoizpen ekologikoa egitea. iv) Euskal Herrian errotutako esperientzia izatea. Kontaktazioak egiteko eta elkarrizketatuak lortzeko elur-bolaren ikerketa teknika kualitatiboa da erabili duguna. Gipuzkoa eta Bizkaian errotutako esperientziak dira guztiak, beraz emaitzak Euskal Herri mailara estrapolatzea ez litzateke analitikoki zintzoa izango. Genero aldetik hiru emakume eta zazpi gizonezko izan dira elkarrizketatuak (ikus eranskinetan fitxa teknikoa). 
Elkarrizketa azpiegituratuak erabili dira ikerketa-teknika bezala eta analisi soziologiko sozio-hermeneutikoa erabili digu interpretazio bide modura (Alonso, 2011). Elkarrizketen helburua ez da izan arrazoi estistiko bati jarraitzea, arrazoi estrukturalak baizik. Kokapen esanguratsuak eta adierazgarriak dituzten hizlariak hautatzen saiatu gara, euren gako diskurtsiboek eskaini diezaguketen informazio baliotsu eta aberatsean sinetsita.

Diskurtsoen analisirako erabili dugun metodoa bakoitzaren kokapenaren zentzu mikro eta makrosoziala ulertzera bideratu dugu. Ariketa hori egiteko bi premisa orokor kontuan hartu ditugu. Alde batetik, jakitun gara elkarrizketatuak historikoki eta sozialki kokatuak dauden moduak diskurtso zehatz batzuk osatzera bultzatzen dituela. Bestetik, elkarrizketatu bakoitzaren diskurtsoak lur hartzen duen eremu komunikatibo eta ideologikoa ere kontuan hartu dugu, funtsezko aldagaia iruditzen baitzaigu edozein diskurtsoren jatorria ulertu ahal izateko.

Orotara, artikulu honetan zortzi sakoneko elkarrizketa aztertzen dira, zortzi esperientzia ezberdinen berri ematen dutenak. Elkarrizketa guztiak banaka eta buruz buru egin dira elkarrizketatu eta elkarrizketatzailearen artean.

\subsection{Kaletik baserrira, gazteak autoeraketa agroekologikoan}

Jarraian analisi enpirikoaren atalean murgilduko gara. Elkarrizketetan atera diren gai adierazgarrienak hautatu dira analisiaren sailkapena egiteko. Sei azpiataletan banatzen da hurrengo kapitulua. Analisirako aukeratu diren pasarteak, jaso ditugun diskurtsoetatik esanguratsuenak deritzogunak izan dira.

\subsubsection{Aldagai Sozioekonomikoa}

Lehenik eta behin, beste ezertan sartu aurretik, elkarrizketatu diren subjektuen gizarte kokapena zein den zehaztea komeni da, edo behintzat, zeintzuk diren biltzen dituzten ezaugarri nagusiak.

Guztiek erakutsi dute hausnarketa jarrera kritiko bat gizarteak markatzen duen bizi eredu normatiboarekin. Denak izan dira herri mugimenduetako kide eta aurretik borroka sozial ezberdinetatik edandakoak dira:

Egia da kalean beti egon izan garela kapitalismoaren aurka borrokan, ezkerretik, gaztetxeetan edo gazte antolakundean militatzen. (E3)

Bageunden herrian saltsan ibiltzen ginen talde bat, gizarte ereduarekin konforme ez geundenak eta berau aldatu gura genuenak. Gaztetxeak behar batzuk asetzen zizkigun baina beste urrats bat eman gura genuen. (E5) 
Horrek noski ibilbide bat erakusten du, gaztetatik sektore sozial jakin batean kokatu izan dira, herri mugimenduen soziologia osatzen duen sektorean hain justu, gizartea interpretatzerako orduan begirada kritiko garatuarekin.

Era berean ezin da bazterrean utzi elkarrizketaturiko gehienak, salbuespenak salbuespen, ekonomikoki arazo larririk izan ez duten inguruetatik datozela. Bada, miseria egoerak edo pobrezia larriko egoerak ezagutu gabeak dira, hau da, burujabetzarako hautua egin bai, baina ahalmen ekonomiko bat behar izan dute hori gauzatzeko. Klase kokapena baldintzatzaile adierazgarria da:

esan behar da gu sozioekonomikoki ez garela sekula miseria egoeran egon, aukera izan dugu hona etorri eta proban jartzeko nahi genuena, ekonomikoki ahalmena geneukan familiatik, hori ere kontuan hartu beharrekoa da. Besterik ez bagenuen, lantegian lan egitea besterik ez zitzaigun geratuko. (E2)

Bertatik ondoriozta liteke, beraz, gutxieneko formazio kritiko-intelektual bat jaso dutela guztiek, bai akademiaren esparruan edo militantzian elikatu direnak. Alegia, denek izan dute baliabide kultural jakinetara sarbidea eta gizarte eredua zalantzan jartzeko gaitasuna eskuratu dute bertan, edo Bourdieu-ren terminoak erabiliz, kapital kultural ertain-altuz jantzitako subjektuak dira. Horrez gain, izan dituzten harreman-sareek, jasotako formakuntzek eta ahal ekonomikoak ahalbidetu dute bide hau jorratzen hasi izana, kapital sozial eta ekonomikoarekin lotura estuan.

20 urte nituela John Zerzanen Futuro Primitibo irakurri nuen, Kropotkin ere bai... estimuluak jaso nituen nolabait. Via campesinako ideia batzuk ere, iraultzaz geroko bizi-eredua ja egiten hasteko esaten zutenak. (E5:H1)

\subsubsection{BurujabetZARI KeINUA}

Sozio-ekologiaren planteamenduetatik gertu dauden hausnarketak batu dira gehienbat. Gutxiagorekin bizitzeko beharra ardatz gisa jarririk, euren bizitzaren jabetza izateko nahia ageri da, euren elikagaiak ekoitzi eta kontsumitzekoa, ahalik eta gutxien joz merkatura. Eguneroko bizitzan ahalik eta kontrol esparru handiena lortzea da helburua:

Ehuneko ehunean burujabe ez dut uste sekula izango garenik, baina oinarrizko beharrak asetzeko badaukat nahikoa hemen. Animalien okela, ogia egin dezakegu, eztia, gazta... Olioa, gatza eta abar bai erosi behar izaten dugu, baina beharrezkoa badaukagu behintzat. Diru askorik ez dugu irabaziko baina segurtasun handia daukagu, bizitzeko elikagaiak eskura 
baitauzkagu edozer gertatzen dela ere, kalitate onekoak gainera, badakigu zer jaten dugun. (E1)

...jendearekin elkartu eta burujabetzaren aldeko bidea egiteko gogoa eta ilusioa izan nuen, taldean antolatu eta burujabe izan zentzu guztietan, bai elikadura, bai energetikoki, medikuntzan ere ezagutzak pilatu... Ez diogu gure buruari ebakuntza bat egingo baina katarro bat sendatzeko gai bagara bada zeozer. (E4:H2)

Gizarteko erakunde nagusiekiko begirada kritiko zorrotza nagusitzen da. Euren burua osasun-sistematik, energia-sistematik edo elikagai hornikuntza-sistematik kanpo kokatu gura dute. Nabarmena da gizartearekiko erakusten duten narratiba kritikoa, eta egin duten hautuaren bihotzean ipar bat aurki daiteke: burujabetza. Ideia horren bueltan hornitzen dute zentzuz euren bizi-estiloa, lanaren banaketa Durkheimdarrarekin bukatu, eta jakintza ezberdinak metatuko dituen indibiduo oso bilakatzea da helburuetako bat. Nolabait, gizarte garaikide sofistikatuetan dagoen elkarmenpekotasun maila arindu gura da, bizitza posible egiten duten esparru estrategikoen kontrola berreskuratuz. Funtsean, milaka urteetan zehar gizakiak naturarekin izan duen harreman bizigarria berreskuratzea bilatzen da. Diskurtso korronte anti-modernoa topatu dugu elkarrizketetan:

Naturak, eguraldiak, animaliek... Zehazten dute gehiago noiz egin behar den lan eta noiz ez. Ez daukat ordutegi finkorik, behar denean egiten ditut zereginak. Neguak eta udak oso ezberdinak dira adibidez, neguan egunak motzagoak dira eta atseden hartzeko balio du gehiago, ariketa fisiko gutxiago eskatzen du urte sasoi horrek. Kalean, argiarekin, zaratarekin... nahastu egin zaitezke, ez duzu horrenbeste antzematen ze urte sasoitan zauden. (E1)

Gizarteko hornidura-sistemekiko autonomia maila altua bilatzea dute bereizgarri. Adierazgarria da burujabetzara hurbiltzeko giltza elikagaien ekoizpena dela kasu guztietan. Gizarte eraldaketaren logika nagusietatik aldentzen da, XIX. eta XX. mendeak ezaugarritu dituzten mugimendu kolektiboak ez bezala, norberaren ekintzaren bidez gizarte eraldaketa modu bat bilatzen dute, landa eremuarekin harreman estuan. Nolabait, euren testuingurura begiratu eta nekazal munduan bide propioa egitea iruditzen zaie dela erresistentzia puntu eraginkor bat eraikitzeko bidea. Modu horretan egin nahi diote ekarpena XxI. mendeko erresistentzia borroka eta gizarte eraldaketa prozesuei:

Neri behin lagun batek esan zidan sistemaren kontra egin nahi baduzu onena jana produzitzea dela. Hori egiten baduzu ezin zaitu kontrolatu, 
bere logikatik irtetzen zara. Orduan izan nuen argi, ni baserrian biziko naiz animaliekin.

Boteretze prozesu modura interpretatu daiteke gazteek bilatzen dutena. Norbere elikagai propioak ekoitzita, inoren menpe ez bizi beharra bilatzen $\mathrm{da}$, eta ondorioz erabakimen altuagoa eskuratu norbere bizitzari dagokion edozein esparrutan. Esanguratsua da beraz baserriaren eta gizarte eraldaketa dinamiken artean egiten den lotura estua; bestela esanda, baserria tresna politiko modura definitzen da, sistemari arrakalak eragiteko potentzial handiko eremutzat joz.

\subsubsection{Nahikotasunaren KULtURa}

Oztopoak oztopo, ez dirudi asetasun sentimendu faltarik dutenik, gustura eta harro daude hartutako bideaz. Agian puntu honetan ñabardura txiki bat egitea komeni zaigu, bakoitzak bere bizi hautuaz egin duen defentsan harrotasuna adierazi badu ere, agerikoa da ez dutela okertu zirela esango, ibilbidearen porrota aitortzen egongo lirateke eta. Beraz, hau kontuan izanik ere, badirudi adierazi duten harrotasuna benetakoa dela, «betetzen» dituen «sinesten duten» zerbaitetan ardazten dute euren diskurtsoa.

eguneroko jardunean gustura baldin bazaude, ez duzu beharrik sentitzen bestela egingo zenituzkeen gauza horiek egiteko (...) Azkenean, hau ezagutzen hasi, bizitzen hasi eta galdetzen diozu zure buruari "ze beste egin behar dut nik ba?», bete zaitzake kulturak edo beste edozerk. Kontua da egiten duzunak bete zaitzala, soldatapeko lana izaten hasten den orduan, malo. Lan-indarra gustuko zerbaitetan erabiltzean datza. (E2)

Beste patxada batez hartzen dira gauzak. Jendeak galdetzen dit, ez da oso lotua baserria? Eta nik esaten dut, ez da oso lotua egunero fitxatzea gogo barik, beti itxaroten arratsaldeko bostak noiz helduko diren edo barixakua noiz helduko den? Hemen 365 egunak gozatzen ditut, betetzen nauen zerbait baita. (E3)

Azkenean askatasun bat da gure bizimodu hau, arduraz betetako askatasun bat, gauzen zentzua ikusten duzu, bizitza zer den ohartzen zara... hori kristona da. (E4:H2)

Ba sinesten dugun zerbaiten egotea, zailagoa izango litzateke niretzat markatu diguten bide horretan egotea ez baduzu horretan sinesten. Benetan barrutik sentitzea betetzen zaituen zerbait dela. (E5:H2)

Erantzun horietan harrotasuna adierazi dutela antzeman liteke, hori kristona da, barrutik sentitzea benetako zerbait dela, eguneroko jardunean 
gustura moduko esaldiekin. Hartu duten bideak ongizatea sortzen diela ematen dute aditzera, ikuspegi baikorra gailentzen da eta helduleku ezberdinak bilatzen dituzte baikortasun hori hornitzeko. Nagusi bat ez edukitzea, euren lanaren jabetza, askatasuna, lantegian bizimodu alienatua ez eraman beharra...

Adierazgarria da kaleko bizitzarekiko kontrakotasuenan eraikitzen dutela euren identitatea. Baserriaren iruditeriak eta landa eremuak ezartzen dituen bizi-erritmoak, modu materialean ezberdintzen dira hiriko bizitzak eskatzen dituen erritmo, aisialdi eta praktika kulturaletatik. Nolabaiteko bereizketa egiten da bizi-estiloaren gaineko irakurketan, aditzera emanez soilik baserriak eskain diezaiekela bizimodu on eta asegarri bat edukitzeko aukera.

Hortaz, trantsizio ekosozialak eskatzen duen eraldaketa kulturalarekin lotuz, gutxiagorekin ere, bizi soilik ez, ondo bizi litekeela azpimarratzen dute. Linz eta kideek (2007) halako bideak hartzearen arrazoiak zeintzuk ziren aztertu zutenean finkatu zuten ardatz nagusienetako bat jarrera indibiduala izan zen. Auto-mugapenerako joera, gogoeta baten ondotik dator. Aberastasuna irudikatzeko bestelako modu bat eraikitzen dute, diruan baino, denboraren jabetzatik eta giza harremanetatik eraikitzen dute aberastasunaren definizioa.

Bizitzeko era zaila izan liteke ingurukoen begietara, ongizate material jakin bati uko egitea baitakar horrek, baina beharren logikan sarturik, sozialki eraikiak direneko ideia garbi azal liteke jaso ditugun erantzunetan. Daramaten bizi-ereduan ez dute sentitzen pribilejioei uko egin behar izan dietenik, euren burua jotzen dute pribilejiodun horrelako hautu bat egiteko aukera izan dutelako.

Pribilejioei uko? Hau da pribilejioa, gu hemen goian gaude eta ez hor beheko zulo horretan. Ez diot honi desabantailarik ikusten, gainera zibilizazioan gaude, ez beste planeta batean. (E5:H2)

...hemen bizitzen pribilegiatua naizela esango nuke. Bakea bilatzen nuen, kaleko zorabio horretan kargatua sentitzen nintzen oso. Agian kalean gaudenean ez gara konturatzen estres batean bizi garela, baina denboratxo bat igarota hemen, beste ikuspuntu batetik begiratzen duzu hiria, nola bizi izan naiz hor? (E1)

Edozelan ere, baserrira itzultzea praktika askatzaile modura ulertzen da. Bizimodu modernoak dakarren azkartasunetik eta alienaziotik ateratzeko bide bezala ulertzen da egin duten hautua, ez erabat hausten duena zibilizazioarekin, baina bai ahalbidetzen norberaren denboraren eta bizi iturrien gaineko jabetza dosi altuak edukitzea. Badirudi, modernotasunak gizakiari eragindako minak arintzeko bidea aurkitzen dutela baserrian eta hari loturiko bizi-estiloan. 
Horrekin loturik, adierazgarria da elkarrizketatu batzuen ibilbidea, industrian emaniko iragana deskribatzen dute. Lantegiak dakarren iruditeria eta baserriaren alderatzen dira, bata kontsumo desenfrenatu batekin lotua, eta bestea bakearekin. Are, lantegian lana (2008ko krisialdiaren aurretik) soldata onarekin eta kontsumorako sarbide oparoarekin lotzen da. Horri uko egiteko borondatea azaldu dute:

Gu 20 urteren bueltan genbiltzanean boom-a suertatu zitzaigun, tailerrean lana egin, dirua irabazi, ostirala iritsi eta desfasea, kontsumoa frenorik gabe. Gero baserrira igo eta gauza guzti horiek alde batera lagatzen dituzu, beste lasaitasun bat daukazu hemen, animaliak zainduz, bakea... «te estas haciendo un viejo» esaten didate lagunek kar-kar. (E3)

17 urterekin tailerrean hasi nintzen lanean, astelehenetik ostiralera lan egin tornilo artean, asteburua iritsi eta juerga, dirua gastatzeko gainera... Gurpil horretan sartu nintzen, baina iritsi zen une bat nahikoa da esan nuena, ea hau ote zen nire bizitzarako nahi nuena, gurpil horretan jarraitzea. (E4:H2)

18 urterekin kotxea nuen, menuak jaten nituen jatetxeetan, pintxoak, alkohola, drogak ere nahi beste... Hasieran oso ondo, baina gero "nik hau ez dut nabi» esan nuen. (E4:H2)

Denbora seriea aztertzen badugu, iragan makur eta iluna deskribatzen da, erabaki puntu batek jarraitua, orainaldi patsadatsu bati bide emateko. Iragan horretan, izan duten sozializazio mekanismoek pisua hartzen dute: nolabait korronteari jarraitzen zioteneko sentipena garatu dute, harik eta gaitasun kritiko batera iritsi eta euren bizi-norabidea aldatzeko ausardia izan zuten arte. Iragan nostalgiko bat deskribatzetik urruti, orainak eta etorkizunak hartzen dute pisu narratiboa, horiek baitira bizmodu emantzipatua garatu ahal izango duten denbora dimentsioak.

Erantzun hauetan ere islatzen da kaleko bizimodu azkarraren arrangura. "Gurpil zoro" gisa definitzen dute egunerokoa, irentsi egiten duela norbera iradokiz. Halaber, esanguratsua da "zahartzen ari zara» moduko esaldien inputa jasotzen dutela. Gaztetasuna azkartasunarekin, indarrarekin eta etengabe mugitu beharrarekin lotzen dela adierazten digu. Ingurukoen pertzepziotik bizimodu pausatuago bat ez dagoela begi onez ikusia ematen dute aditzera.

Era berean, aipagarria da goiko aipuetan euren iraganeko bizi ibilbidearen hutsaltasuna deskribatzen dutela. Frustrazioaren eta asegabetasunaren ideiari loturik, euren eguneroko jarduna zentzuz hornitzeko zailtasunak zituztela deskribatzen dute. Interesgarria zaigu puntu honetan forma subjektibo garaikidearekin ezartzen den kontrakotasuna, normatiboki ezarritako bizi-ibilbidea pausuz pausu jarraitzeak ezinegona eta noraez sentipena era- 
giten baitzien, eta behin ibilbide horretatik aterata aurkitu dute identifikazio esparru propio eta asetzailea.

\subsubsection{TalkaK eta muga KulturalaK}

Baserrirako bidea egiteak ordea, sortzen ditu inguruan gatazka eta talka kulturalak. Ez da ulergarria euren hautua, ez eta erakargarria ere, nortasun handia eta konbentzimendua erakutsi behar izan dutela azaltzen dute:

Batez ere gurasoek ez zuten ulertu era honetako erabaki bat hartzea. Une zailak izan ziren, baina gero gustura nengoela ikusi eta onartu zuten poliki-poliki, hasierako beldurrak apaltzen joan ziren. "Besteek zer esango dute?" galdetzen zioten euren buruari. Bestalde, lagunek ere "Nola duzu hain garbi?" "nolatan» moduko galderak egiten zizkidaten, baina egon ziren asko lagundu nindutenak ere. Argi neukan zein zen jorratu gura nuen bidea, beste asko noraezean ikusten ditut. (E1)

Nire gurasoekin arazoak izan nituen, gogorrak gainera. Ez zuten ulertzen ikasketak edukita nola aukeratu nezakeen diru gutxirekin bizitzea, lanpostu on bat izan dezakezula uste dute. (E4:H1)

"Aspertuko dira", "zentzuzko zerbait egingo duzue behingoz?" moduko komentarioak entzun behar izan ditugu. Pertsona bat ortuan sartzen bada, ikasten, lanean, ikertzen eta sortzen ez omen daki zertan ari den; aldiz, errelebo kontratu prekario batean sartzen dena zerbait zentzuzkoa egiten ari da. (E2)

Gurasoek ez zuten ulertzen egin nahi nuena "ze ostia zabiltza ingeniaritza bat eta lana edukita?", amamak ere esaten zidan "gu baserritik jaitsi ginen eta zer egin behar duk hik han goian,? Ez dago ezer egiteko han", lagunak ere... (E3)

Guztiek azaldu dute inguruan talka gogorrak eragin dizkiela. Modu nahiko homogeneoan agertu da gurasoen figura, egindako hautuaren erresistentzia puntu modura. Familia erakunde sozial modura agertzen zaigu kudeatu beharreko lehen talka gisa, eta puntu horretan estigmatizazio prozesuaren elementu batzuk ageri zaikigu (Goffman, 1986). ${ }^{11}$ Estereotipoak

11 Aspalditik datorren kontzeptu soziologikoa da estigmarena, Erving Goffman soziologoak teorizatu zuen gaia (Goffman, 1986). Berak dioenez jarrera, jokamolde edo ezaugarri jakin bat izateagatik, pertsona bat gizarte kategoria zehatz batean kokatzen da eta bertako kideak gutxietsi egiten dira, kulturalki onartezintzat edo mespretxagarritzat joz. Estigmatizatua den norbanakoak ingurukoen ukoa jasan beharra dauka, mespretxua eta gutxiespena. Horrek sortzen duen ondoez psikologikoarekin. 
eraikitzeko joera oso bizirik daukagu prozesu honetan, zein den horrelako hautua egiten dutenenganako irudikapena, zein ezaugarri atxikitzen zaizkien: «aspertuko dira», «gazte ameslariak», «ideologiatik ezin da bizi» eta gisako esaldiak jaso ditugu, ingurukoek hala ikusten zituztela arrazoituz, beroaldian harturiko erabakia bailitzan.

Hau esanik, estigma ezartzerako orduan eraikuntza kultural errotuak daudela ohar gintezke, soldatapeko lanaren onespena, ekonomia korronte nagusiari aitortzen zaion balioa, agroekologiaren jarduna gutxiestea, gizarte kokapen erdi-altu batetik jauzi egiteko nahia ulertu ezina, ezkerreko ekologista militanteen pentsamendua "ameskeria» gisa ikustea, errealitatetik erabat kanpokoa... Iruditeria kultural ezberdinak mugiarazten dira, modernitatearen garapen eta hazkuntzaren narratibaren talaiatik eraikiak. Trantsizio ekosozialean murgiltzen diren gazteen erabakiaren arrazoiek talka egiten dute gizarteen azpikorronteetan martxan dauden zenbait logika sistemikorekin eta bizimodu ontzat eraikia dagoen paradigma kulturalarekin.

Aztergai ditugun talkek elkarrizketatuen dimentsio defentsibo altua erakusten dute, gurasoen, gertukoen eta harreman afektiboak dituztenen ukoa jasoagatik, tentsio-puntua mantendu eta erabakiari eutsi diote. Nortasun sendoak agertzen zaizkigu, errotiko desadostasunak dituztenak ingurukoen bizi-estiloekin. Indibidualtasun maila altua eta konbentzimendua oinarrizko osagaiak izan dira euren proeiktuak aurrera atera ahal izateko. Paradoxikoa badirudi ere, gizarte modernoak ahalbidetzen dituen inidibidualtasunek eta nortasun bereiziek egin dute posible bizimodu modernotik atera gura duten esperientzien eraikuntza. Bestela esanda, gizarte aurremodernoen dimentsio komunitario gogor eta diziplinatzaileei begiratzen badiegu, izaera propio eta partikularren eraketa mugatuagoa zegoen. Beraz, egin duten hautua adar indibidualistatik interpretatzerik badago, nolabait komunitateak dituen arazoetatik urrundu eta norberari baliagarri zaion espazioa irekitzearekin zerikusia duena.

\subsubsection{LUR-JABETZAREN ARAZOA ETA ERAKUNDEAK}

Lur-jabetzaren arazoa dela eta, elkarrizketatu guztiek modu homogeneoan planteatu duten gaia izan da. Hautua ondo gorpuzteko arazo nagusi gisa dute lurrarena. Beste talka sistemiko bat identifikatzen dugu hemen, oraingo honetan kulturala bainoago, materiala:

Arazoa da gure herrian lur gutxi daudela eta dauden apurrak jabego pribatuen esku daude. Horri buruz gutxi hitz egiten da, baina gazte batek era honetako bidea jorratu gura badu lur jabetzaren arazoa hor izango du. (E2) 
...lehen herri lurrak ziren hauek baina guztia pribatizatu da. Ekimen interesgarriak badaude, Lurtzaindia sortu zuten iparraldean, 3.000 bazkidek osatzen dute, eta denen artean erosten dute lur bat gazte batek baserrira joan nahi badu. Orduan, lur horiek herriarenak izango dira, ez dira jabe bakarrarenak izango. Kapitalismoari oztopo bat jartzen zaio horrela. (E1)

Gaztea nintzenean talde bat batu eta okupatzera sartzen ginen, dena konpondu, berriztu... baina guztia ondo jartzen zenuenean zipaioak etorri eta ospa... behin eta berriz kontu bera...orduan gauzak ezberdin ikusten dira, pixkat nazkatuta lur-sail bat erosteko hautua egin genuen, diru pixka bat egin eta gero... Beti egin eta desegin... nekeza da. (E4:H2)

Euren proiektua eraikitzeko duten premia materialak buruhausteak eragiten dizkie. Lurren jabetza komunala aipatzen da, erakundeek eskuhartzearen premia eta horrelako ekimenak babesteko dagoen gizarte babes falta nabarmena. Uraren korrontearen kontra igeri egiteak dakarren nekea aipatzen da, bazterreko kokapen sozial batean egotera eraman dituena, nahiz eta konbentzimenduz aritu.

Halaber, udalerri txiki batzuetan martxan jarri diren neurri batzuk goraipatu ondotik, azpimarragarria da ia elkarrizketa guztietan EHNE Bizkaia erakundea ageri izana. Bai agroekologia ikastaroak sustatzen dituelako edo bestelako bizi eredua planteatzen duelako erakunde nagusien aurrean, Jaurlaritza eta abar. Zentzu horretan, gizarte zibil antolatutik lortzen duten babes politiko eta ideologiko apurra erakunde horrek eskaintzen diela azpimarratzen dute.

Erakunde bakarra ikusten dudana hau bultzatzen duena EHNE Bizkaia da, elikadura burujabetza kontzeptua defendatzen dute erakundeen aurrean, zorte ona opa diet, diru publikoa AHT moduko proiektu faraonikoetara baitoa. (E5:H1)

\subsubsection{ELKARBIZITZAREN KUDEAKETA, ADAR INDIBIDUALAREN HAUTUA}

Jaso diren esperientzietan identifikatu den beste oztopo nabari bat elkarbizitzaren kudeaketarena izan da. Elkarrizketatuek baserrira taldean joateko esperientziak deskribatu dituzte, ez direnak kudeatzen errazak izan. Gatazka iturri horren arrazoietan arakatzen hasirik, guztiek egiten diote erreferentzia bizi-estilo indibidualizatuen pisuari, izan dituzten sozializazio prozesu eta heziketa moldeek tentsio estrukturalak sortzen dituzte gaztaroan abiatutako elkarbizitza proiektu kolektiboan:

Ni horrelako proiektu batetik nator eta oso oso zaila da. Inguruan entzun ditudan esperientzi gehienak ere ez dira oso ondo bukatu. Kaletik ba- 
koitzak bere mobidak ekartzen ditu, ohiturak, maniak... Niretzako kristona da kolektiboki antolatzearena eta horrelako proiektu bat aurrera ateratzea.

Beti arazoak sortzen dira elkarbizitzan, denbora eta esfortzu asko galtzen da gauzak erabakitzen, mahai gainean galtzen da indar dena, bileretan, adostasunak bilatzen... Indar fisiko zein mental asko galtzen genuen hor, hemen orain nik hartzen ditut erabakiak eta asmatu edo kale egin nire ardura da... ez dakit... Bakoitzak bere istoriak dauzka eta talkak egon litezke.

Iruditzen zait horrelako proiektuek aurrera egiteko oso garrantzitsua dela formatutako jendea izatea. Ohitua dagoena erabakiak kolektiboki hartzera, militatu duena eta gatazkak nola kudeatu dakiena, funtsezkoa da hori. (E3)

Nik hautu hau egiten dutenei esango nieke ondasun materialak bai landu behar direla baina aspektu emozionala lantzen hasteko albait lasterren. Azkenean ez daukagu tresnarik alderdi horiek lantzeko, etxe bat eraikitzeko gai gara baina ez elkarbizitza on bat sustatzeko. Jendearekin bizitzeak ispilu bat edukitzea etengabe aurrean eskatzen du, pertsona moduan baino proiektu moduan pentsatu behar da. Oso berekoiak gara. (E5:H2)

Alderdi materiala lantzeari lehentasuna ematea arriskutsutzat jotzen da, alderdi emozional eta kulturala aldi berean lantzen ez bada. Ongizate kolektiboa posible izan dadin, kaleko bizitzatik ekarritako oinordetzak lantzearen garrantzia azpimarratzen da bakoitzaren mania, mobida edo istoriak inertzia gatazkatsuak dituztela iradokiz. Ildo horretan, formakuntza prozesu bati egiten zaio erreferentzia, taldean aberastasun materiala partekatuz bizitzea ikasketa prozesu modura definituz eta jasotako heziketa zein harremantze moduak berrikusteko jarreraren premia azpimarratuz. Funtsean, berriz egiten dugu topo garai modernoak sortutako subjektuarekin. Nortasun sendoa proiektu agroekologikoetan sartzeko aurrebaldintza izan bada ere, proiektu horren garapen arrakastasurako oztopo ere bada neurri batean. Esaterako, erabaki-esparruen gatazka planteatzen da denbora eta esfortzu asko galtzen da gauzak erabakitzen. Eremu ez-eraginkor modura interpretatzen dira asanblada edo bilerak: are gehiago, ez da uste kaletik jasotako oinordekotzetatik askatzea posible denik eta nolabaiteko porrot sentipena nagusitzen da. Hortaz, bakarrik aurrera eramandako proiektuei zilegitasuna eman nahi zaie taldean bizimodua egitearen ezinezkotasuna planteatuz.

Azken hori, gako diskurtsibo justifikatzaile modura interpretatu daiteke, elkarbizitzaren kudeaketak eskatzen duen dimentsio anitzeko problematika konplexuegitzat joz, eta proiektu agroekologiko arrakastatsuak batez ere bakarrik edo bikotean egin daitezkeela aditzera emanez. Puntu 
honetan, indar berezia hartzen du esperientzia hauen adar indibidualistaren azalpenak, elkarrizketatuen artean interpretazio ezberdinduak egon badira ere.

\section{Emaitzen interpretazioa}

Jasotako material diskurtsiboaren azterketa sozio-hermeneutikoa egin ondotik, gako nagusi batzuk aipatzeko moduan gara. Ideietako bakoitzean sakontzeak lan honi dagokion luzeera eta tamaina gainditzea eskatzen badu ere, lau ardatz nagusi aipatuta utzi nahi ditugu, aztergai dugun fenomenoaren gainean argi-puntu interpretatibo batzuk adierazte aldera.

\subsection{Hautu espresiboa}

Aipatu da egungo subjektu hegemonikoaren jarduna merkatuari begirakoa dela, motibazio instrumentala du nagusi. Aztertu ditugun subjektuen bizi-jardunaren nolakotasuna, aldiz, bestelakoa dugu. Bistan da landa-eremura joan izanaren funtsezko arrazoia ez dela merkatuan ohorezko lanpostua erdiestea (arrakasta material-instrumentala); aitzitik, euren nortasunaren adierazteko modua da.

Egunerokotasunean jarduera jakin horiek burutzean izaera jakin bat adierazten ari zaizkio inguruari, zein mundu ikuskera duten, nortzuk diren, zein zentzu ematen dioten egiten dutenari, zergatik diharduten egunero diharduten bezala. Nortasunaren adierazpen etengabekoa genuke, izan nahi luketeenerakin eta direnarekin koherentzia bilatuz, ahal dela.

Hala ere, gutxieneko hautu instrumentalista egon badagoela ezin daiteke esan gabe utzi. Bizi jarduna ogibide bilakatu dute, hortaz, irabazi ekonomikoa ez da erabat baztertzen, merkatuari muzin eginda bizitzea ia ezinezkoa baita gaur egungo koiuntura neoliberalean. Garbi dago, ordea, dikotomia horretan, motibazio instrumentala vs espresiboa, espresiboa gailentzen dela nabarmen, etekin emozionalaren bilakuntza gehiago baitago ekonomikoa baino; bestela esanda, nahiago da norbere buruarekin «betea» «aseta» «gustura» sentitu, soldata altua poltsikoratzea baino.

\subsection{Borondatea jatorri}

Automugapenaren ideiarekin loturik, garrrantzia berezia hartzen du nekazal bidearen borondatezko izaerak. Eredu ekonomiko nagusitik ateratzen den eremu bat sortzea dute bulkada nagusi, eta euren eguneroko praktike- 
kin bestelako harreman sozial eta ekonomikoak gorpuztea bilatzen dute. Horregatik diogu borondatea dutela jatorri eta ez beharra. Ez dira 2008ko krisi ekonomikoaren eztandak bultzaturik bazterrean geratu diren subjektu prekarizatuak, beste irtenbiderik gabe bide hori hartu behar izan dutenak. Aitzitik, hautuak ekar zitzakeen ondorioez erabat jakitun (egonkortasun zein onarpen orokorrari uko egitea, besteak beste) aurrera egitea erabaki zuten, proposamen kontra-hegemoniko batetik. Euren jardunari eransten dioten esanahi politikoa beraz, helburu instrumentaletatik haratago doa. Kasu gehientsuenetan industria sektoreko lanak utzi (aitortu digutenez, ongi ordainduak eta kontsumo oparora sarbidea eskaintzen zutenak) eta nekazal eremuan proiektu propioa abiatzeak eros-ahalmen terminoetan galera handiak eragin dizkie. Ordea, garatu duten bizi-estiloa asegarriago zaie emaitza orokorrari begiratuta; bestela esanda, dimentsio materialean galdu arren, dimentsio psikokultural eta existentzialean asetasun maila altuak lortzen dituzte.

Pentsamendu sozio-ekologikoak azken urteetan eratu duen markoarekin eta trantsizio ekosozialak eskatzen duen eraldaketa kulturalarekin loturik, funtsezkoa zaigu esperientzia guztietan errepikatu den ezaugarri hau azpimarratzea. Euren narratibetan, borondatezko automugapena ez dute sakrifizioaren eta esfortzuaren ideiarekin lotu, aitzitik, askapenarekin, bakearekin eta bizi-estilo asetzaileekin lotu dute. Riechmannek planteatzen duen luxuzko pobrezia kontzeptuarekin lotura eginez, nahikotasunaren kultura aplikatzea bizipen aberasgarrietarako bide dela frogatzen dute euren lekukotasuneik. Alabaina, nabarmena da biziera austero hori lorpentzat deskribatzeko, irakurketa kritiko zabala, kapital kultural handia eta ausardia altuko izaerak izan direla aurrebaldintza. Irekitzen zaigun galdera, beraz, automatikoa da, nola orokortu irakurketa hori, oparotasun materialean eroso bizi den gizarte aberatsean?

\subsection{Logika hegemonikoaren eraldaketa}

Talka nagusiak zeintzuk izan dituzten ezagutu ostean, ekonomia eta merkatua ulertzeko modu jakin batek sortutako tentsioak identifikatu ditugu. Soziologiatik subjektuaren eraikuntza aztertu izan denean garbi geratu da ezinezkoa dela subjektu idealaren sorrera bere determinazioetatik kanpo (Leff, 2010). Alegia, ez daukagu izaterik baldintza nagusietatik kanpo, baina horrek ez du agortzen subjektuen ekintzak daukan eraldaketarako gaitasuna. Luze eta zabal emango luke egitura eta agentziaren arteko eztabiada soziologiko zaharrean murgiltzeak. Dena den, gure postura Muiñoren berba hauetan laburbiltzen da ondoen: $n i$ sometidos a la fatalidad de la historia como un oráculo, ni superhombres capaces de replantearlo 
todo desde la ingeniería social: el lugar propio de lo humano es un pequeño margen para el equilibrismo entre nuestra frágil libertad y nuestras fuertes determinaciones (Santiago Muiño, 2015: 143).

Afera soziologiko zaharra dugu. Subjektibazio moduez ari gara, zer behar den subjektibotasunak aldatu ahal izateko; gizartea aldatuz subjektibotasunak aldatuko dira edo subjektibotasunak aldatuz eraldatuko da gizartea?. Auzi honen inguruko aipu soziologiko azpimarragarria dugu Marcuseren ohartarazpen hau:

Orduan ohartu nintzen, Frankfurteko eskolaren eraginpean, zalantza barik, marxismoak ez ziola behar bezala begiratu oinarrizko alor bati: iraultza egin nabi bada, aurrebaldintza ezinbestekoa da kontzientzien eta inkontzientzien eraldaketa sakona; izan euren psikologian, beharretan edo egitasmoetan. (...) Gatazka nagusia hor dago nire iritziz, nola lortu gizakion eraldaketa sakon bat oinarrizko erakunde politiko eta sozialen aldaketa iraultzailea baino lehenago. (Marcuse, 1986, 84. or. Itzulpen propioa) ${ }^{12}$

Aztertu ditugun esperientzietan, Marcuse-k ohartarazten duen eraldaketa bilatzen da. Elkarrizketatuek zein bizi-baldintza ekonomiko eta politiko dituzten kontuan izanda, bestelako eredu batzuk eraikitzeko eginahalean dabiltza, betiere euren praktika propioarekin helburu horretara lor daitezkeela sinetsirik. Eguneroko bizitza eta praktika mikroak politizatzen dituzte, aldi berean sentituz eraldaketa erradikalak eragiten dituztela inguruarekin harremantzeko eretan, eta bizi-ibilbidea eraikitzerako orduan. Euren jardunarekin ez dute iraultza orokorrik edo ortzimuga utopikorik irudikatzen; aitzitik, egunerokoan desberdin jokatuz gizarte eraldaketa sakona posible deneko konbentzimenduarekin dihardute. Eraldaketa mikroan, egunerokoan egin daitekeela uste da, prozesu eraldatzaile makro zabalagoen zain egon gabe. Modu horretan ulertzen dute eurek eraldaketari egiten dioten ekarpena. Puntu honetan trantsizio ekosozialari nola aurre egin galdetzen duen eztabaidari euren ekarpena egiten diote dimentsio politikokultural esanguratsuarekin: trantsizio ekosozialak eskatzen duen erronka zibilizatorioari aterabidea ez da soilik etorriko globalizazioaren uzkurtze, estatuaren esku-hartze, eta langile zein herri klaseen kontra-botere antolatutik; praktika txikiekin errsistentzia puntu indartsua(goa)k sor daitezke, eta aterabide errealagoak bilatu norbere eguneroko ekimenaren bidez.

12 "Entonces fui consciente, bajo la influencia, sin duda, de la Escuela de Frankfurt, de que el marxismo habia descuidado un aspecto fundamental: una de las condiciones previas a la revolución es un cambio radical en la conciencia y en el inconsciente de los individuos, en su psicología, sus necesidades y aspiraciones. (...) El problema central para mi ha sido siempre saber cómo se puede obtener este cambio radical de los hombres antes del cambio revolucionario de las instituciones de base, sociales y politicas." 


\subsection{Erakundeak eta lur-jabetza, ekonomia sozialarekin berbetan}

Identifikatu dugun beste traba nagusia lurren erabilera pribatua izan da. Aurreko puntuarekin erabat loturik dagoen gogoeta dugu honakoa, logika hegemonikoaren parte baita jabetza pribatuaren derrigortasuna. Iruditeri berria lantzeko administrazioak izan ditzakeen tresnak oso dira baliagarriak eta efizienteak, gizartearen esparru anitzetarako irismen ahalmena baitute. EHNE-Bizkaia moduko erakundeen lana abiapuntutzat harturik, beharrezkoa ikusten da era honetako proiektuak biderkatzea, erakunde nagusiei kontsumoan, ekoizpenean eta bizi-ereduan aldatzeko beharra adierazteko, datu zientifikoak eskutan.

Ekonomia Sozial eta Solidarioak azken urteetan landu dituen alor ezberdinak erabilgarriak izan daitezke langintza horretarako. Arrillagak eta Ruiz de Galarretak (2020) planteatutako irakunkortasun sendoko erakundeen lerroan kokatu dezakegu elkarrizketatuen artean aipatu den EHNEBizkaia, ikuspegi ekologista modu transbertsalean zeharkatzen baitu eta epe-luzeko begiradarekin heltzen baitio elikadura-burujabetzaren edota kontsumo arduratsuaren auziari. Zehazki, ingurumen-iraunkortasunerako REAS-ek jasotzen duen txostenean (2011) abeltzaintzarako eta nekazaritzarako behar besteko espazioa edukitzearen premia azaleratzen da, horretarako lurralde-antolakuntza plan egoki eta proportzionala garatuz.

Jasotako erantzunetatik ondorioztatzen dugu, ordea, gaur indarrean dauden hirigintza eta espazio banaketaren ordenamenduek ez dutela begirada ekologikoa bere egiten, esperientzia agroekologikoak abiarazi nahi dituzten gazte ekintzaileek oztopo burokratikoekin eta jabetza arazoekin egiten dutelako topo. Bada, Ekonomia Sozial eta Solidarioak proposatutako ildoan, lan honetan udal administrazioek zein Foru Aldundiek hirigintzaren plan orokorrak eta espazio ordenamenduak berritzean, jasangarritasun irizpideak kontuan hartzea funtsezko auzia izango dela ondorioztatzen dugu, baldin eta era horretako esperientziak biderkatzea eta elikadura-burujabetzan sakontzeko erabaki politikoa hartu nahi bada.

\section{Zenbait ondorio eta aurrera begirako iker-ildoak}

Guztiarekin, ikerlan honen ekarpenak krisi sozio-ekologiko globalak eskatzen duen jokabideen, praktika zehatzen eta ikasgai baliotsuen zerrendari argi puntu batzuk erantsi gura izan dizkio, jada martxan dauden praktika emantzipatzaile auto-mugatuak aztertuz xxı. mendeko Euskal Herrian. Guztia birplanteatzea eskatzen duen erronkaren aurrean gaudela jakitun, paradigma kultural hegemonikotik aldentzen diren bizi-erak aztertu ditugu eta balizko trantsizio berdinzale eta demokratiko batean era honetako 
esperientziek jokatu dezaketen papera aletu. Nortasun sendoak eta begirada kritikoak agertu zaizkigu, baserrira proiektu agroekologiko batekin bizitzera joateko erabakia hartu dutenak eta inguru sozial hurbilarekin tentsio-uneak eta gatazkak kudeatzeko ahalmena eduki dutenak. Bi ezaugarri horiek (nortasun sendoa eta ingurukoen ukoari aurre egiteko ausardia) antzeko esperientziak biderkatzeko muga modura ageri zaizkigula deritzogu.

Halaber, maila eta tamaina horretako trantsizioak eskatzen duen hegemonia kulturala eraikitze bidean, funtsezkoa zaigu esperientzia hauen borondatezko izaera, eta gogobetetasun sentipena ezaugarri adierazgarri bezela azpimarratzea. Subjektu neoliberalaren indartzea bizi dugun garaiotan, nekez irudikatu liteke baliabide urrien agertokian aberastasunaren banaketa erdi-justua egiteko baldintza subjektiboak egongo direnik, ez baldin bada tokian tokiko errealitateetan esperientzia autoeratzaileen sare antolatu eta sendoa eraikitzen. Gure kasuan, agroekologiaren bidetik egin diren hautuak aztertu ditugu, baina berdin balio lezake energiaren esparruan, finantzen alorrean edota ekonomia sozial eta ekologikoaren ardatzean eraikitzen ari den beste edozein esperientziaren azterketak, arreta puntua bere dimentsio subjektiboan jarririk.

Trantsizio ekosoziala gauzatze bidean, dimentsio piskiko-kulturalak zentraltasun berezia hartzen du eta berau aztertzea beharrezko zaigu, zertaz egina dagoen ikusi eta ondoren erladaketak proposatzeko. Funtsean, edozein emantzipazio esperientziak kontuan hartu behar duen gaia da subjektuarena, eta uste dugu giza subjektibotasunean dauden ertz ezberdinak aletuz eta euren gaineko zientzia soziala eginez soilik irudikatu ahalko dugula trantsizio ekosozial egingarriago bat, harimutur ezberdinak josteko borondate metodologikoarekin, betiere.

Azkenik, trantsizio sozio-ekologikoak eskatzen duen sistema sozialaren deskonplexutasunera subjektibotasun garaikidea zein modutan egokitu daitekeen ikertzeko bidea arakatzea bereziki interesgarria izango litzatekeela uste dugu. Sistema sozial orok behar ditu hari moldagarriak izango zaizkion izaerak ekoitzi, eta prozesu horretan faktore kulturalak, ekonomikoak, politikoak edo erliiosoak sartzen dira jokoan. Eremu horietako bakoitzean subjektuari zein errenuntzia egitea eskatuko liokeen zehaztea premiazko ariketa iruditzen zaigu, ukapen horietako bakoitza zein beste modutan asetu litekeen pentsatzen hasteko, asetasun gabeziaren sentipena nagusitu ez dadin. Bestela esanda, desazkunde material bortitz bati nolabaiteko kontrapisua egingo dioten dispositibo kultural eta politikoak zein modu zehatzetan gauzatu daitezkeen jakiteko, aurrenik zein sakrifizio material egongo diren eta horietako bakoitzak molde subjektibo garaikidean ze inpaktu izan dezakeen identifikatzea oso jakintza baliagarria izango zaigu, trantsizio ekosozialaren ertz mingarrienak nolabait neutralizatu ahal izateko, baita dimentsio subjektiboan ere. 


\section{Bibliografia}

Alonso, L.E (2013): «La sociohermenéutica como programa de investigación en sociología». Arbor, 761, 1-15.

Areskurrinaga, E. Begiristain, M eta Malagón, E. (2019) Elikadura-sistemak: Elikadura Burujabetzaren eta Agroekologiaren estrategia askatzaileak. Hegoak Zabalduz, 10, EHU.

Arrillaga, P eta Ruiz de Galarreta, J (2020). «Ekonomia Ekologikoaren eta Ekonomia Sozial eta Solidarioaren arteko hurbilketa. Agenda baterako elementu bateratuak." Gizaekoa, Revista Vasca de Economía Social, 17, 35-70.

Atutxa, E eta Zubero, I (2019) «El paradigma de lo común para la transición ecosocial: Prácticas democráticas para la recuperación ciudadana de la energía.» RIESISE. Vol 2, pp 51-76.

Azkarraga. J (2014) «Harrigintza berria» Jakin, 202: 11-42.

Azkarraga. J, Neef. M, Funders. F, Altuna.L (2011) La evolución sostenible (II) Apuntes para una salida razonable, LANKI-Mondragon Unibertsitatea.

Azkarraga, J eta Aurélie, A (2017). «Youth Producing Food for an Alternative Society: Insights from the Basque Country,»in A.A. Desmarais, P. Claeys and A. Trauger (eds.) Public Policies for Food Sovereignty: Social Movements and the State, Routledge Studies in Food, Society and the Environment, Routledge, London

Bouchard, MJ (2011) Léconomie social, vecteur d'innovation: léxperience du Quebec. Presses de lúniversité du Québec. Québec.

Bourdieu, P. (1983). Poder, Derecho y Clases Sociales. Desclée.

Burns, T. Baumgartner, T. Deville, P. (1985) Man, Decisions, Society: The Theory for Actor-System Dynamics for Social Scientists. Nueva York, Gordon and Breach.

Calle, A. Soler, M eta Rivera-Ferre, M-G (2011) «Soberanía alimentaria y agroecología emergente: la democracia alimentaria.» In Aproximaciones a la democracia radical, ed. A. Calle, 213-237. Barcelona: Icaria.

Diamond, Jared (2006): Colapso. Por qué unas sociedades perduran y otras desaparecen, Debolsillo. Madril.

Fernandez Durán, R eta González Reyes, L (2014) En la espiral de la energía. Libros en Acción. Madril.

Fisher, M (2016) Realismo Capitalista ¿No hay alternativa?. Caja Negra. Buenos Aires.

García Olivares, Antonio et al. (2012). «A global renowable mix with proven technologies and common materials", Energy Policy. $41 \mathrm{znb}$.

Goffman, E. (1986 [jatorrizko ed. 1963]). Estigma. La identidad deteriorada. Buenos Aires: Amorrortu.

Hardt, M. Negri, T. (2002) Imperio. Buenos Aires, Paidós.

Herrero, Y. (2011), «Vivir bien con menos; ajustarse a los límites físicos con criterios de justicia», Viento Sur, 108. zenb.

Laval, C., Dardot, P. (2013) La nueva razón del mundo. Madrid, Gedisa. 
Laville, JL eta García, J (2009) Crisis capitalista y economía solidaria. Icaria. Bartzelona.

Laville, JL (2010) Politique de l'assotiation. Èditions du Seuil. Paris.

Leff, E. (2010) «El desvanecimiento del sujeto y la reinvención de las identidades colectivas en la era de la complejidad ambiental» Polis, 27.

Linz, M. (2007): «Sobre suficiencia y vida buena», en M. Linz, J. Riechmann y J. Sempere, Vivir (bien) con menos. Sobre suficiencia y sostenibilidad, Icaria, Barcelona.

Löwy, M (2011). Ecosocialismo, La alternativa radical a la catastrofe ecológica capitalista. Ediciones Herramienta, Buenos Aires.

Marcuse, H. (1986) «Socialismo o barbarie. Entrevista con Herbert Marcuse» in Materiales de sociología critica, La piqueta.

Marx, K (1977 (jatorrizko ed. 1987)) El capital (critica de la economía política), Vol. I, Madrid: Akal.

Max-neef (2006) «Development and human needs» Real-Life Economics. Understanding Wealth Creation, Londres eta Nueva York, Routledege Press.

Metereologiaren Munduko Erakundea (2021) State of the Global Climate, 2020. World Meterological Organization.

Monsangini, G. (2007), «Decrecimento y cooperación internacional», Rebelión.

Naredo, José Manuel (2006). Raíces económicas del deterioro ecológico y social. Madril: Siglo XXI.

Polanyi, K. (1992) La grán transformación.Los orígenes politicos y económicos de nuestro tiempo. Mexico. Fondo de Cultura Económica.

REAS, Red de Redes de Economía Alternativa y Solidaria (2011): Carta de principios de la economía solidaria.

Riechmann, J. (2011) «Frente al abismo» Papeles de relaciones ecosociales y cambio global, Mientras Tanto, $95 \mathrm{znb}, 45-71$ or.

- (2013) El siglo de la gran prueba. Tegueste (tenerife), Baile del Sol.

- (2015). Autoconstrucción. La transformación cultural que necesitamos. Los Libros de La Catarata: Madrid.

- (2016) El no actuar en aquellos dias... Apuntes sobre la crisis ecosocial. Foro Transiciones. Madril.

Reichmann, J eta Carpintero, O (2013) «Pensar la transición: ensañanzas y estrategias económico-ecológicas.» Economía Crítica, 16, 45-116.

Santiago Muiño, E (2015) Opción cero: Sostenibilidad y socialismo en la Cuba postsoviética: estudio de una transición sistémica ante el declive energético del siglo XXI. Madril. UAM.

Santos, B eta Rodriguez, C (2007) Para ampliar el canon de la producción. Otra Economía. I (I), 8-13.

Schweickar, D. (2006) «Democracia Económica: una propuesta para un socialismo eficaz", in ARRIOLA, J. (ed.), Derecho a decidir. Propuestas para el socialismo del siglo XXI, El Viejo Topo, Madril.

Sempere, J (2016) Fuhem Ecosocial. Entrevista a Joaquim Sempere. 2016ko abenduaren 5a. Hemen eskuragarri: https://www.fuhem.es/2016/12/05/entrevistaa-joaquim-sempere-2/ 
Tanuro, D (2011) El imposible capitalismo verde. La Oveja Roja, Madril.

Trainer, T (2015) The case for Sinplicity. Simplicity Institute Report.

Turiel, A (2012) El declive energético. Mientras Tanto, 117, 11-26.

Wright, E, O (1997). Reflexiones sobre socialismo, capitalismo y marxismo. Secretaría de Estudios y Programas de CC.OO. de les Illes Balears, Palma de Mallorca.

Zubero, I. (2012) «Nuevos y viejos actores de la transformación social» Cambio Social y cooperación en e l siglo XXI, 1: 23-30.

\section{Eranskinak}

Egindako elkarrizketen fitxa teknikoa:

\begin{tabular}{|c|c|c|c|}
\hline Kodea & $\begin{array}{c}\text { Elkarrizketatu } \\
\text { kopurua }\end{array}$ & Aldagai soziodemografikoak & Kontaktazioa \\
\hline $\begin{array}{l}\text { 1. Elkarrizketa } \\
\text { (E1) }\end{array}$ & 1 & $\begin{array}{l}\text { - Gizonezkoa } \\
\text { - } 34 \text { urte } \\
\text { - Kaletik baserrira joana } \\
27 \text { urterekin. Abeltzain- } \\
\text { tza du jarduera nagusi }\end{array}$ & $\begin{array}{c}\text { - Azataporrua Ei- } \\
\text { barko kontsumo } \\
\text { kooperatiba agroe- } \\
\text { kologikoaren bidez. }\end{array}$ \\
\hline $\begin{array}{l}\text { 2. Elkarrizketa } \\
\text { (E2) }\end{array}$ & 1 & $\begin{array}{l}\text { - Gizonezkoa } \\
\text { - } 26 \text { urte } \\
\text { - Kaletik baserrira hiru la- } \\
\text { gunekin } 24 \text { urterekin. } \\
\text { - Ortugintza du jarduera } \\
\text { nagusi }\end{array}$ & $\begin{array}{l}\text { - Kontsumo koope- } \\
\text { ratibatik jasotako } \\
\text { kontaktua (bertara } \\
\text { ermaten ditu bere } \\
\text { saskiak) }\end{array}$ \\
\hline $\begin{array}{l}\text { 3. Elkarrizketa } \\
\text { (E3) }\end{array}$ & 1 & $\begin{array}{l}\text { - Gizonezkoa } \\
\text { - } 28 \text { urte. } \\
\text { - Kaletik baserrira } 27 \text { urte- } \\
\text { rekin, abeltzaintzan oina- } \\
\text { rritutako proiektu batera. }\end{array}$ & $\begin{array}{l}\text {-2. Elkarrizketatutik } \\
\text { eratorritako kontak- } \\
\text { tua. }\end{array}$ \\
\hline $\begin{array}{l}\text { 4. Elkarrizketa } \\
\text { (E4) }\end{array}$ & 1 & $\begin{array}{l}\text { - Gizonezkoa } \\
\text { - } 29 \text { urte } \\
\text { - Industriatik baserria } \\
\text { jauzi. } \\
\text { - Abeltzaina. }\end{array}$ & $\begin{array}{l}\text {-2. Elkarrizketatutik } \\
\text { eratorritako kontak- } \\
\text { tua. }\end{array}$ \\
\hline
\end{tabular}


BIZI-HAUTUAK ERTZETATIK. ESPERIENTZIA AGROEKOLOGIKOEN DIMENTSIO SUBJEKTIBOA ...

\begin{tabular}{|c|c|c|c|}
\hline Kodea & $\begin{array}{c}\text { Elkarrizketatu } \\
\text { kopurua }\end{array}$ & Aldagai soziodemografikoak & Kontaktazioa \\
\hline $\begin{array}{l}\text { 5. Elkarrizketa } \\
\text { (E5 H1) } \\
(\text { E5 H2) }\end{array}$ & 2 & $\begin{array}{l}\text { H1 (lehen hiztuna) } \\
\text { — Emakumezkoa } \\
\text { - } 31 \text { urte } \\
\text { - Kaletik baserri koopera- } \\
\text { tibo batera } 23 \text { urterekin. } \\
\text { - Jarduera anitzak } \\
\text { H2 (bigarren hiztuna) } \\
\text { - Gizonezkoa } \\
\text { - } 30 \text { urte } \\
\text { - Kaletik baserri koopera- } \\
\text { tibo batera } 25 \text { urterekin. }\end{array}$ & $\begin{array}{l}\text {-4. Elkarrizketatutik } \\
\text { eratorritako kontak- } \\
\text { tua. }\end{array}$ \\
\hline $\begin{array}{l}\text { 6. Elkarrizketa } \\
\text { (E6 H1) } \\
(\mathrm{E} 6 \mathrm{H} 2)\end{array}$ & 2 & $\begin{array}{l}\text { H1 (lehen hiztuna) } \\
\text { — Gizonezkoa } \\
\text { — } 33 \text { urte } \\
\text { — Proiektu komunitario ba- } \\
\text { teko kide. Nekazaria eta } \\
\text { itzultzailea. } \\
\text { — Jarduera anitzak } \\
\text { H2 (bigarren hiztuna) } \\
\text { — Emakumezkoa } \\
\text { — } 35 \text { urte } \\
\text { - Okupazio mugimendu- } \\
\text { tik dator, burujabetza- } \\
\text { rako hauru irmoa egina. } \\
\text { Nekazaria eta landa ere- } \\
\text { muko ekintzailea. }\end{array}$ & $\begin{array}{l}\text { EHNE-Bizkaia elkarte } \\
\text { agroekologikotik lor- } \\
\text { tutako kontaktuak. }\end{array}$ \\
\hline $\begin{array}{l}\text { 7. Elkarrizketa } \\
\text { (E7) }\end{array}$ & 1 & $\begin{array}{l}\text { - Gizonezkoa } \\
\text { - } 32 \text { urte } \\
\text { - Lantegia utzi eta landa } \\
\text { eremuko proiektu agroe- } \\
\text { kolokigora jauzi. } \\
\text { - Ortugintza } \\
\end{array}$ & $\begin{array}{l}\text { 4. Elkarrizketatutik } \\
\text { eratorritako kontaktua. }\end{array}$ \\
\hline $\begin{array}{l}\text { 8. Elkarrizketa } \\
\text { (E8) }\end{array}$ & 1 & $\begin{array}{l}\text { - Emakumezkoa. } \\
\text { — } 34 \text { urte. } \\
\text { — Proiektu komunitario ba- } \\
\text { teko kide, elikadura bu- } \\
\text { rujabetzaren aldeko ekin- } \\
\text { tzailea. }\end{array}$ & $\begin{array}{l}\text { 2. Elkarrizketatutik } \\
\text { eratorritako kontaktua }\end{array}$ \\
\hline
\end{tabular}

